IZA DP No. 8674

Intergenerational Mobility of Housework Time in the United Kingdom

J. Ignacio Gimenez-Nadal José Alberto Molina

Yu Zhu

November 2014 


\title{
Intergenerational Mobility of Housework Time in the United Kingdom
}

\author{
J. Ignacio Gimenez-Nadal \\ University of Zaragoza
}

José Alberto Molina

University of Zaragoza

and IZA

Yu Zhu

University of Dundee

Discussion Paper No. 8674

November 2014

\author{
IZA \\ P.O. Box 7240 \\ 53072 Bonn \\ Germany \\ Phone: +49-228-3894-0 \\ Fax: +49-228-3894-180 \\ E-mail: iza@iza.org
}

\begin{abstract}
Any opinions expressed here are those of the author(s) and not those of IZA. Research published in this series may include views on policy, but the institute itself takes no institutional policy positions. The IZA research network is committed to the IZA Guiding Principles of Research Integrity.

The Institute for the Study of Labor (IZA) in Bonn is a local and virtual international research center and a place of communication between science, politics and business. IZA is an independent nonprofit organization supported by Deutsche Post Foundation. The center is associated with the University of Bonn and offers a stimulating research environment through its international network, workshops and conferences, data service, project support, research visits and doctoral program. IZA engages in (i) original and internationally competitive research in all fields of labor economics, (ii) development of policy concepts, and (iii) dissemination of research results and concepts to the interested public.
\end{abstract}

IZA Discussion Papers often represent preliminary work and are circulated to encourage discussion. Citation of such a paper should account for its provisional character. A revised version may be available directly from the author. 


\section{ABSTRACT}

\section{Intergenerational Mobility of Housework Time in the United Kingdom}

This paper analyzes the relationship between parents' time devoted to housework and the time devoted to housework by their children. Using data from the Multinational Time Use Study for the UK, we find positive intergenerational correlations in housework for both parents, indicating that the more time parents devote to housework, the more time their children will devote to housework. However, when endogeneity of the uses of time are considered using the British Household Panel Survey, we find that only fathers' housework time appears to have a statistically significant effect. The IV estimates fully support the FE estimates and suggest that father's housework induced by his partner's non-traditional gender role attitudes towards domestic division of labour and her actual labour supply in the previous wave, has a large and significant effect on children's housework time. Our results contribute to the field of intergenerational mobility of behaviors.

\section{HIGHLIGHTS}

- study intergenerational mobility of housework using time use data and panel survey

- time use survey results show positive effect of both parents' housework time

- however, fixed-effect results indicate that only fathers' housework time matters

- father's housework instrumented by mother's non-traditional gender role attitudes

- instrumental variable results consistent with fixed-effect estimates

JEL Classification: J16, J22

Keywords: housework, household, intergenerational transfers, Multinational Time Use Study, British Household Panel Survey

Corresponding author:

Yu Zhu

Economic Studies

University of Dundee

3 Perth Road

Dundee, DD1 4HN

United Kingdom

E-mail: y.u.zhu@dundee.ac.uk

\footnotetext{
* This paper was partially written while José Alberto Molina was Visiting Fellow at the Department of Economics of Boston College (US) and Yu Zhu was visiting the Department of Economics of the University of Zaragoza (UZ), to which they would like to express their thanks for the hospitality and facilities provided. This paper has benefited from funding from the Spanish Ministry of Economics (Project ECO2012-34828). The MTUS data was provided by the Centre for Time Use Research (CTUR) at the University of Oxford. The BHPS data was supplied by the UK Data Service and used with permission. We are grateful for comments from Yu Aoki, Donald Cox, Daniel Hamermesh, Almudena Sevilla, Alexandros Zangelidis, and seminar participants at University of Zaragoza, University of Aberdeen and University of Dundee.
} 


\section{Introduction}

Parents and children are, in the majority of cases, genetically related and they usually live together. In these circumstances, we can presumably expect transmissions of behaviors, which have two fundamental set of motivations: altruism and exchange. The economic study of altruism dates from the initial work of Adam Smith (1759), who argued that inter-dependence among individuals provides positive utility, measured in economic terms. Edgeworth (1881) justified this inter-dependence in terms of the “social distance” between individuals. Later, Becker (1981), and Becker and Barro (1988) established that, in altruism, the transfer is motivated by the donor's concern for the well-being of the recipient, with no expectation of compensation. The alternative approach, the exchange or self-interest motivation, widely developed by Cox (1990), Cox and Rank (1992), Altonji et al. (1992), and Cigno (1993), is based on the fact that individuals obtain utility from transfers to children because they expect to receive some form of compensation in the future. ${ }^{1}$

The relationship between inter-generational transfers and equality of opportunities has been studied in the literature, identifying certain circumstances through which parents may give their children an advantage, such as the transmissions of monetary and time investments, as well as transfers of values and social behaviors. For instance, the economic theory of intra-household resource allocation suggests that parental investment could compensate for (Becker and Tomes, 1976) or reinforce (Behrman et al., 1982) initial differences in endowments. Although empirical evidence has been found in favor of parents compensating for differences in initial endowments of children (Griliches, 1979), the bulk of the empirical evidence points toward parents reinforcing such differences (Behrman et al., 1982; Rosenzweig and Schultz, 1982; Rosenzweig and Wolpin, 1988; Pitt et al., 1990; Behrman, et al., 1994; Ayalew, 2005; Datar et al., 2010). The study of transfers across generations or, more broadly, inter-generational mobility (the relationship between the socio-economic status of parents and the status of their children during adulthood), reflects the extent to which individuals move up, or down, the social ladder relative to their parents.

The gendered division of housework has been universally observed and extensively

\footnotetext{
${ }^{1}$ See Molina (2013 and 2014) on non-monetary in-kind transfers, and on monetary transfers from both inter- and intra-generation perspectives, respectively, as examples of studies analyzing altruistic behaviors in the household. Transfers can also be found between individuals of different households, with some evidence analyzing whether these private transfers are driven by altruistic or non-altruistic motives (Cigno et al., 1998). Transmission behaviors also appear between private and public individuals.
} 
studied. This pattern is confirmed by Figure 1, based on a sample of couples with children aged 11-18 year in the British Household Panel Survey (BHPS). It shows that while there is a clear negative correlation between mother's share of housework and her share of market work, her housework share never goes under $70 \%$, regardless of whether she (and indeed her partner) has post-secondary education (denoted as Higher Education, or HE).

A literature on intergenerational correlation of housework time using time use surveys has only emerged very recently (see e.g. Álvarez and Miles (2012) and Solaz and Wolff (2015)), invariably pointing to a positive effect of parental housework on children's housework. However, these studies are all descriptive. For policy interventions, it is vital to identify the causal link in the intergenerational mobility of housework.

Against this background, we examine the relationship between the housework time of parents and that of their children, and explore the potential channels of the transmission of housework time from generation to generation. To that end, we first use diary data for the United Kingdom (2000), which contains information on individual activities throughout the 24-hour day. ${ }^{2}$ We find positive correlations between parents' and children's housework time for the UK: a difference of $10 \%$ in the time devoted to housework by fathers and mothers, translate into a difference of $1.6 \%$ and $1 \%$ in the time devoted to housework by their children, respectively. ${ }^{3}$

However, previous results do not take into account the possible endogeneity across the uses of time of the different members of the household. It could be that parents' housework time has a direct influence on their children's housework time. But it could also be that parents use housework time as a way to spend more time with their children and thus it is children's housework time that has a direct influence on their parents' housework time instead. Additionally, there can be unobserved factors at the household

\footnotetext{
${ }^{2}$ It has been shown that diary-based estimates of time use are more reliable and accurate than estimates derived from direct questions on how much time respondents have spent in the reference week on market work or housework in household survey (Juster and Stafford, 1985; Robinson, 1985; Robinson and Godbey, 1997; Bianchi et al., 2000; Bonke, 2005; Klevmarken, 2005; Kan, 2008).

${ }^{3}$ To our knowledge, no existing data would allow the estimation of intergenerational correlation of housework time at the same age range. However, the long panel of the BHPS allows us to check the persistence of these teenagers' housework time into early adulthood. For example, for the sample of 16-18 year olds who had been tracked till they were at least 25 in the BHPS, the correlation coefficient of housework time between the first and the last wave (on average 12 years apart) is around 0.19 and statistically significant at $0.1 \%$.
} 
level that make individuals of some households devote more time to housework (e.g., higher preference for cleaner dwellings) which explains the positive relationships found between parents and children's housework time. Under this framework, the previous analysis based on time-dairy data yields biased coefficients, and thus we cannot talk about causality but just about correlations.

To deal with the issue of causality, and given the absence of appropriate instruments for parents' housework time in the UK time use survey, we alternatively use BHPS, a long panel survey of households in the UK with information on weekly housework hours for all adults aged 16 and above in all waves, and categorical information on housework for young people aged 11-15 in more recent waves. First, we estimate fixedeffect (FE) models which allow for time-invariant unobservables which might confound parents' housework time and bias intergenerational mobility estimates in conventional time use studies using cross-sectional data. Here we find that only fathers' housework time appears to have a statistically significant effect. Second, we further explore lagged gender role attitudes and lagged actual labour supply of the mother to instrument father's housework time. The Instrumental-Variable (IV) estimates fully support the FE estimates and suggest that father's housework induced by his partner's non-traditional gender role attitudes towards domestic division of labour and her weekly working hours in the previous wave, has a large and significant effect on children’s housework time.

We contribute to the existing literature on the inter-generational mobility of behaviours and attitudes. Despite the existence of many studies of inter-generational transmission of values and attitudes, happiness and economic outcomes, few papers have directly analyzed inter-generational transmission of the uses of time. To the extent that housework time represents a significant portion of daily life and negatively impacts on women's labour supply, this paper focuses on a relevant issue. Second, while previous studies on time allocation decisions have greatly enhanced our understanding of what factors affect these decisions (Gershuny, 2000, 2009; Aguiar and Hurst, 2007; Kalenkoski et al., 2005; Connelly and Kimmel, 2007 ,2009; Hamermesh and Lee, 2007; Gimenez-Nadal and Molina, 2013), most of them are descriptive. By using both the FE and the IV methods, we present suggestive evidence of a causal link between the time allocation decisions of members of the same household in this paper.

The rest of the paper is organized as follows. Section 2 reviews the literature. Sections 3 shows the results obtained using time diary data. Section 4 shows the results 
obtained with the BHPS. Section 5 sets out our main conclusions.

\section{Literature review}

Roemer (2004) formally discusses the relationship between inter-generational transfers and equality of opportunity and considers three categories of circumstance through which parents may give their children an advantage. First, parents may influence life chances through the genetic transmission of personality, preferences, or health. Second, parents may transmit economic advantage through social connections, facilitating access to jobs and/or access to sources of human capital. Third, parents may influence the lifetime earnings of their children through a family culture and other monetary and nonmonetary investments.

The literature has largely confirmed inter-generational transmissions of preferences or attitudes. ${ }^{4}$ Wilhelm et al. (2008), for the US, estimate the correlation between the generosity of parents and the generosity of their adult children, finding that the elasticity of children's giving with respect to parents' giving ranges from 0.26 to 0.31 for religious donations, and from 0.08 to 0.14 for secular donations. Grønhøj and Thøgersen (2009) find positive correlations when examining parent-child similarities of general values, as well as specific attitudes and behaviors in the environmental domain, using a sample of Danish families. Bulte and Horan (2011) propose an empathy model of cultural transmission to capture the evolution of preferences in a population. Dohmen et al. (2012) analyse the inter-generational transmission of risk and trust attitudes, finding positive evidence of this. Necker and Voskort (2014) investigate whether children and parents show a similar willingness to take risk in their choice of occupation in Germany, and find that fathers' earnings risk is significantly positively related to sons' earnings risk despite that intergenerational transmission is weak in terms of effect size.

Gimenez-Nadal and Molina (2013) analyze the relationship between parents’ education and the time devoted to childcare activities, using Spanish and UK time-use data, finding that mothers' education is associated with an increase in the time devoted to educational childcare by fathers in both countries, while it is associated with an

\footnotetext{
${ }^{4}$ Previous research has also identified inter-generational transmissions of cognitive abilities/schooling (Anger and Heineck, 2010; Kirchsteiger and Sebald, 2010; Holmlund et al., 2011; Black and Devereux, 2011; Tsou et al., 2012; Stella, 2013), earnings/income (Solon, 1999, 2002; Hendricks, 2007; McIntosh and Munk, 2009; Corak, 2013) and well-being (Winkelman, 2005; Casas et al., 2005; Clair, 2012; Carlsson et al., 2013).
} 
increase in the time devoted to educational childcare by mothers only in Spain. Croft et al. (2014) find that fathers who help with household chores are more likely to raise daughters who aspire to traditionally male dominating (and potentially higher paying) careers.

Previous research has proposed several competing theories on the division of labor at home (see Auspurg et al. (2014) for a review). The specialization theory proposed by Becker (1965) establishes that if one partner is relatively more productive than the other in market work, the household utility will be maximized if that partner specializes in market work while the other specializes in housework. However, if the partners have identical levels of human capital, we should observe that both sexes doing similar shares of market work and housework, which goes against recent evidence on the distribution of household labor (Brines, 1994; Aguiar and Hurst, 2007; Gimenez-Nadal and Sevilla; 2012). Alternative theories have been proposed to reconcile with empirical evidence, which includes that of social gender norms (Lennon and Rosenfield, 1994; Baxter and Western, 1998; Bianchi et al., 2000). This theory refers to the existence of societal gender norms that limit the power of women in both within the household and in the society, which makes women stick to a predetermined gender role where women are most responsible of household work. However, these gender roles are effective only if deviating behaviors are socially sanctioned or if norm-compliance is rewarded. Given the weakness of these mechanisms in modern societies, an alternative explanation for individuals conforming to the existing gender norms is because they internalize them (e.g., gender identity as proposed by Akerlof and Kranton (2000)). The model of gender identity assumes that social gender norms are internalized and thus individuals who choose work arrangements which deviate from arrangements prescribed by social gender norms will incur a penalty in their utility compared to individuals whose choices affirm their gender self-image. Auspurg et al. (2014) reject the theory of gender identity in an experimental context using the UKHLS Innovation Panel and they find no evidence that men's preferences differ systematically from those of women, or that either men or women prefer the traditional male breadwinner arrangements.

Sociologists have studied gender role attitudes for a long time (Mason, Czaka and Arber, 1976; Thornton and Freedman, 1979; Tallichet and Willits 1986; Mason and Lu, 1988; Peek et al., 1991; Cassidy and Warren, 1996). Recently, Crompton et al. (2005) study the association between gender role attitudes and the domestic division of labour 
in Britain, Norway and the Czech Republic. While they find a significant negative relationship between liberal gender role attitudes and traditional domestic division of labour in all three countries in 1994, such association becomes insignificant for Britain and Norway in 2002. Berrington et al. (2008) highlight the reciprocal relationships between changes in women's gender role attitudes and the changes in their labour force participation, following entry into parenthood.

It is only recently that economists have turned their attention to gender role attitudes, partly because of the new availability of this information in household survey data. Farré and Vella (2013) study the effect of mothers' attitudes towards working women on her children's attitudes, using the National Longitudinal Survey of Youth (NLSY79) and the Young Adults of the NLSY79. They find evidence of cultural transmission between parents and children, which in turn affect not only the labour market participation of daughters, but also that of the daughters-in-law. Using the 1970 British Birth Cohort (BCS70), Johnston et al. (2014) present compelling evidence of maternal gender role attitudes on her daughters' educational and labour market outcomes, measured some 25 years apart. While there appears to be no direct effect of mothers' attitudes on sons' education and labour supply, they find a significant correlation with sons’ partners' labour supply. Using the BHPS, Schober and Scott (2013) consider how couples adapt gender role attitudes and employment decisions in the transition to parenthood. Their findings suggest that couples with strong maternal postnatal labour market attachment are more likely to have less traditional attitudes.

\section{The United Kingdom Time Use Survey (2000)}

For the analysis of the relationship between parents and children's housework time, we use data from the United Kingdom included in the Multinational Time Use Survey (MTUS). ${ }^{5}$ The MTUS is an ex-post harmonized cross-time, cross-national, comparative time use database, coordinated by the Centre for Time Use Research (CTUR) at the University of Oxford. It is constructed from national randomly-sampled time-diary studies, with common series of background variables, and total time spent in 41 activities (Gershuny, 2009). The MTUS provides us with information on individual time

\footnotetext{
${ }^{5}$ Information on the variables, and on how to access the data, is available on the MTUS website: http://www.timeuse.org/mtus. See Fisher, Gershuny and Gauthier (2011) for a full description of the MTUS documentation. We use version W53 (accessed in October 2010) of the MTUS.
} 
use, based on diary questionnaires in which individuals report their activities throughout the 24 hours of the day.

\subsection{Sample selection}

We select individuals who are between 11 and 18 years old, who are living with two heterosexual parents. Furthermore, in order to analyze how the housework time of parents relates to the housework time of their children, we need time-use information for both members of the couple. This limitation prevents us from carrying out a more general and up-to-date analysis, as we must restrict the analysis to the 2000 survey as it is the only UK survey included in the MTUS that has been harmonized and that has information for all the members of the household.

The MTUS activities are defined as the 'primary' or 'main' activity individuals were engaged in at the time of the interview, and we are able to add up the time devoted to any activity of reference (e.g., paid work, leisure, housework) as 'primary' activity. We consider the time devoted to housework by both parents and their children, measured in hours per day. Our definition of housework includes the total time devoted to the following activities: “cook, wash up”, "housework”, “odd jobs”, “shopping” and “domestic travel”. Table 1 shows the time devoted to housework by children and their parents for the UK. Children devote around 0.5 hours per day to these activities, while fathers and mothers devote 0.91 and 1.56 hours per day, respectively. ${ }^{6}$ This gender gap in housework of mothers is consistent with Gimenez-Nadal and Sevilla (2012) who find a gender gap in housework favoring women in the UK during the 2000s.

Furthermore, non-participation in housework activities on a daily basis is more common for fathers and children compared to mothers. Figure 2 shows k-density functions for the time devoted to housework activities for children, mothers and fathers. We can observe that a higher proportion of children (28.3\%) and fathers (13.5\%) report no participation in housework activities compared to mothers (1.7\%), and that housework time has a greater variation for children and fathers compared to mothers, as

\footnotetext{
${ }^{6}$ In a previous version of the paper, we also analyzed the time use patterns of children and their parents for Germany (2001), Italy (2002) and Spain (2002) using surveys included in the MTUS. A common characteristic of this pattern is that in all the countries children devote around 0.5 hour per day to housework. Additionally, mothers in Italy and Spain devote a relatively high amount of time to housework compared to mothers in Germany and the UK, which is consistent with prior studies showing that in the Mediterranean countries there is a large gender gap in housework favoring women, which makes these countries especially inegalitarian in the gender distribution of household labor (Sevilla, 2010; Sevilla et al., 2010; Gimenez-Nadal et al., 2012). Results are available from authors upon request.
} 
the Coefficient of Variation (CV) yield higher values in the case of children (CV=0.32) and fathers $(\mathrm{CV}=0.46)$ compared to mothers $(\mathrm{CV}=0.30)$. Hence, housework time is more evenly distributed for women whereas there is more daily variation in the time devoted to housework by fathers and their children. Such differences may indicate that while participation in housework activities is more sporadic for fathers, involvement in housework for mothers can be seen as a "normal" behavior of the household members, consistent with previous evidence on gender roles (Álvarez and Miles, 2003; Bittman et al. 2003; Evertsson and Nermo, 2004; Gimenez-Nadal, Molina and Sevilla, 2012) and the existence of typical "male" and "female" tasks (Cohen, 1998, 2004; Hersch and Stratton, 2002; Sevilla et al., 2010) where "male" tasks are sporadic and refers to household maintenance and odd jobs. ${ }^{7}$ All this evidence may indicate that fathers' time in housework is more important for the behavior of children as it could be considered as exceptional (e.g., father's involvement could be more important at the margin).

This last hypothesis is reflected in the raw correlation or relationship between children and parents' housework time. Figure 3 shows the raw relationship between children's and parents' housework times. The figures plot the average time devoted to housework by children for each time devoted to housework of the parent; that is, for all households with the same amount of time devoted to housework by the father/mother, we average the time devoted to housework by the children, by gender. For instance, for all households where the father devotes 1.04 hour to housework, we average the time devoted to housework by the children, obtaining a mean value of housework of 0.61 hours per day. We then (scatter) plot mean housework time of children (y-axis) on the time devoted to housework by fathers and mothers (x-axis). We have also added a linear fit to see the extent to which scatters are distributed following a linear relationship.

We observe a positive relationship between the time devoted to housework by parents and the time devoted to housework by their children. Furthermore, comparing the slopes of the linear fits obtained for mothers and fathers' housework time, we observe that the slope is higher for the case of fathers' housework. In particular, while the slope for fathers' housework is 0.21 , the slope for mothers' housework time is 0.11 , which is consistent with the idea that fathers’ housework time has a greater influence on

\footnotetext{
${ }^{7}$ According to a recent survey carried out in the UK for 1,000 working mothers, when asked about who takes primary responsibility of the different household chores in their homes, men are responsible for only 3 activities (empty the bins, change light bulbs and do a spot of DIY) while women are responsible for 36 activities which includes cooking, ironing and cleaning, among others (www.mumsnet.com).
} 
children's housework time compared to that of mothers.

\subsection{Empirical strategy}

Using an adaptation of Black and Devereux (2011) and Stella (2013), who examined human capital transfers, we regress the time dedicated to housework by the children on the time devoted to housework by the fathers and mothers of those children. In this sense, we regress the log of housework time of children on the log of housework time of the father and the mother. ${ }^{8}$ We thus estimate the following OLS model: ${ }^{9}$

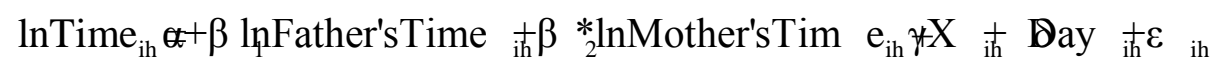

where the dependent variable $\ln \mathrm{Time}_{\mathrm{in}}$ denotes the log of the time devoted to housework by child “i” in household " $h$ ", with this being expressed as a linear function of (log) time dedicated by parents to housework in the household. The indicators of mobility $\beta_{1}$ and $\beta_{2}$ represent the elasticity of children's time with respect to their parents' time, with an elasticity of 0.5 implying that a $10 \%$ difference between two families translates into an average difference of roughly 5\% between their children's times. Even though we use the logarithm of housework of parents and their children, the transformed variables do not follow a normal distribution, which makes the error terms of regressions not homoskedastic, and thus we correct our regressions by obtaining robust standard errors.

The set of socio-demographic variables $X_{\text {in }}$ includes the children's characteristics (gender, age, and work status), parent's characteristics (age, education, work status) and household characteristics (household size, number of children, and whether the household owns the dwelling). ${ }^{10}$ We specifically include parents' ages to capture

\footnotetext{
${ }^{8}$ We add the unity to the time devoted to housework time before taking logs to allow for zero hours.

${ }^{9}$ However, as we observe a high proportion of "zeros" in the time devoted to housework (23\% of observations in the pooled sample), there can be some dispute regarding the selection of alternative models, such as that of Tobin (1958). According to Frazis and Stewart (2012), OLS models are preferred in the analysis of time-allocation decisions, and Gershuny (2012) argues that traditional diary data can still produce accurate estimates of mean times in activities for samples and subgroups. Foster and Kalenkoski (2013) compare the use of Tobit and OLS models in the analysis of the time devoted to childcare activities, finding that the qualitative conclusions are similar for the two estimation methods. Thus, we rely on OLS models, although we have alternatively estimated Tobit models, and our qualitative conclusions are the same (results shown in Appendix). It is not possible to apply a conditional Fixed-Effects Tobit model as there does not exist a sufficient statistic allowing the fixed effects to be conditioned out of the likelihood (Greene, 2004), and thus we rely on a Random-Effects Tobit model when considering the panel data structure of the data.

${ }^{10}$ Column 1 in Table 1 shows means and standard deviations for our explanatory variables.
} 
differences in housework time behaviors across parental lifecycles, and day-of-the-week dummies to scale the day of the week (ref.: Saturday). Finally, $\varepsilon_{\text {ih }}$ represents a robust standard error.

\subsection{Results}

Column (2) in Table 1 shows the results of estimating Equation (1) on the time devoted to housework by children. We find positive correlations between parents' and children's housework time, indicating that the more time parents devote to housework, the more time their children devote to housework. In particular, we find correlations of 0.11 and 0.08 between fathers' and mothers' housework time, on the one hand, and the time devoted to housework by their children on the other. Given that children's and parents' housework time has been transformed to logarithm, we can interpret these results in terms of elasticities: a difference of $10 \%$ in the time devoted to housework by fathers translates into a difference of $1.06 \%$ in the time devoted to housework by their children, while a difference of $10 \%$ in the time devoted to housework by mothers translates into a difference of $0.75 \%$ in the time devoted to housework by their children. Additionally, $\beta_{1}$ seems to be larger compared to $\beta_{2}$, consistent with the evidence shown in the above analysis. However, a t-type test does not allow to affirm that the 2 coefficients are statistically different from each other ( $\mathrm{p}$-value=0.40), and thus at this stage we cannot ascertain that the relationship for mothers and fathers' housework is different.

Two issues here prevent us from talking about causality. First, reverse causality may imply that there exists an effect of children's housework on the time devoted to housework by their parents and, under this framework, simple econometric models that do not take into account this two-way relationship would yield biased estimations. ${ }^{11}$ However, the limitation in the socio-economic information included in the UKTUS precludes an Instrumental Variable strategy. Second, one might be concerned with the presence of unobserved heterogeneity of individuals and households as there might be unobserved factors at the individual and household level that correlate with both the time children devote to housework, and that of their parents. Factors such as parents' heterogeneity in time preferences, and in the outsourcing of household chores, or

\footnotetext{
${ }^{11}$ To the extent that children and parent's housework time are substitutes, this would bias the estimates towards zero. If anything, this would make it harder to find a significant effect of parent's housework (i.e. it works in our favour).
} 
heterogeneity in productivity of individuals in housework, are just a few examples of factors that can affect the time devoted to housework by parents and their children at the same time.

\subsection{Results considering unobserved heterogeneity}

Given that the MTUS is cross-sectional, we cannot identify correlations between parents' and children's housework time net of (permanent) individual and household heterogeneity in preferences. However, we now exploit the fact that we have two diaries per individual, which allows us to exploit the within-person variation in housework time and thus control for permanent individual/household heterogeneity in preferences. Comparing the within-person and between-person variation of our dependent variable, we obtain a within-person variation of 0.37 , while the between-person variation is 0.46 , respectively. Thus, we have sufficient within-person variation to apply a Fixed Effects estimator on equation (1). Unfortunately, we have no time-variant variables except for days when the diary was answered, which are included in the regressions, and thus we take these results as complementary and not as main results, given that we cannot control for the observed heterogeneity of children and their parents. There are 932 distinct individuals.

Column (3) in Table 1 shows the FE results. We observe that both fathers' and mothers' time in housework are positively related to the housework time of children, with these associations being statistically significant at standard levels, and consistent with previous results without taking into account the unobserved heterogeneity of individuals. Thus, it appears that the unobserved heterogeneity of individuals and households does not alter our main results: in the UK both fathers' and mothers' housework is positively related with the time devoted to housework by the children. In particular, a difference of $10 \%$ in the time devoted to housework by fathers translates into a difference of $1.6 \%$ in the time devoted to housework by their children, while a difference of $10 \%$ in the time devoted to housework by mothers translates into a difference of $1 \%$ in the time devoted to housework by their children. Additionally, $\beta_{1}$ seems to be larger compared to $\beta_{2}$, consistent with the evidence shown in the above analysis, but again a t-type test does not allow to affirm that the 2 coefficients are statistically different from each other (p-value=0.28). 


\subsection{Results for ratios of housework}

We propose an alternative way to control for the permanent heterogeneity of individuals/households preferences for housework by normalizing housework time for parents and children. The reason is that different types of households may have different preferences for housework time (e.g., by family size or age of the parents) and thus both the father and mother devote more time to housework as they prefer, for instance, a cleaner house. Thus, we normalize the housework time of the father, and the child, by dividing by the mother's time in housework in the household, as mothers present a higher participation rate in housework time. We define the "Child-mother housework ratio" and the "Father-mother housework ratio" as follows: $\begin{aligned} & \text { Child }- \text { mother } \\ & \text { housework ratio }\end{aligned}=\frac{\text { Child's Time }}{\text { Mother's Time }}$ and $\quad \begin{aligned} & \text { Father }- \text { mother } \\ & \text { housework ratio }\end{aligned}=\frac{\text { Father's Time }}{\text { Mother's Time }}$.

Columns (4) and (5) in Table 1 shows the results of regressing the "Child-mother housework ratio" as function of "Father-mother housework ratio", for the OLS and FE specifications respectively. ${ }^{12}$ We find that the "Father-mother housework ratio" is positively related with the "Child-mother housework ratio" for both the OLS (e.g., 0.245) and FE (e.g., 0.263) models. These results indicate that the higher the time of the father in housework the higher the time devoted by the child to housework, relative to the time devoted by the mother, pointing toward the more important role played by father's housework in explaining the time devoted by the child to housework.

\subsection{Heterogeneous effects}

We now analyze the relationship between parents' and children's housework time when we consider that these relationships may vary depending on the economic status of the parents. For instance, it could be that, in those couples where one of the members does not participate in the labor market, the members of such couple are more concerned about their children's behavior and well-being (single-earner couples have stronger preferences for raising their children by themselves). As a result, we could expect different patterns of behavioral transmission, e.g., larger correlations of parents' housework with the housework of their children. To that end, we consider the economic

\footnotetext{
${ }^{12}$ Here we do not apply the logarithm to the ratios, as they would lead to negative values for the two ratios.
} 
and labor status of parents as a conditioning element.

First, we consider the labor status of the mother. This analysis is relevant to the extent that some couples may both participate in the labor market, using their additional income - compared to one-earner couples - to outsource the household chores. Under this framework, it could be that in dual-earners couples the relationship between parents and children's housework time differs from the relationship in one-earner couples. We thus consider whether the mother is working or not, as typically the father participates more often in the labor market.

Columns (1) and (2) of Table 2 show the results of estimating Equation (1) for households where the mother is working, and the mother is not working, respectively. We observe that for the two types of households, fathers' housework is positively related with the time devoted to housework by the children, results that are consistent with previous results. In particular, a difference of $10 \%$ in the time devoted to housework by fathers in households where the mother works translates into a difference of $0.9 \%$ in the time devoted to housework by their children, while a difference of $10 \%$ in the time devoted to housework by fathers where the mother does not work translates into a difference of $1.6 \%$ in the time devoted to housework by their children. Thus, the relationship between fathers and children's housework time almost doubles in households where the mother does not work compared to households where the mother works. Furthermore, mothers' housework is positively related with children's housework time at the $90 \%$ confidence level in households where the mother works, while it is non-statistically significant in household where the mother does not work. Thus, the relationship between fathers and children's housework time is larger in households where the mother does not work, which may be explained as follows: in specialized couples, where the father works and the mother does most of the household chores, the participation of the father in this household chores may be seen as something exceptional and thus has a larger influence on the behavior of their children.

A second factor that may condition the correlations observed in the analysis that includes all the couples is education. It could be that more educated parents are more concerned about the educational and attitudinal behavior of their children. On the other hand, it could be that as more educated parents have a higher opportunity cost, they devote less time to housework, compared to less-educated parents, which negatively affects the positive correlation between parents' and children's housework time. Thus, 
we estimate Equation (1) considering 3 possible levels of education of the mother: primary education (less than high school level), secondary education (high school level) and university education (some college, college degree or more).

Columns (3), (4) and (5) of Table 2 show the results of estimating Equation (1) for couples where the mother has primary education, secondary education, and university education, respectively. We find that the positive correlation between fathers and children's housework time applies to all households independently of the educational level of the mother, with these correlations being statistically significant at standard levels. In particular, a difference of $10 \%$ in the time devoted to housework by fathers translates into a difference of $1.1,0.8$ and $1.2 \%$ in the time devoted to housework by their children in households where the mother has primary, secondary and university level of educations, respectively. But considering the mothers' time in housework, it is only statistically significant in households where the mother has university education, as a difference of $10 \%$ in the time devoted to housework by mothers translates into a difference of $2 \%$ in the time devoted to housework by their children.

In summary, we find that while fathers' housework time is positively related with their children's housework in all cases, the effect of mothers' housework time depends on the type of household. This difference points towards fathers' housework time having a direct effect on the housework of their children, while the effect of mother's housework time is not so clear cut. To disentangle with these heterogeneous effects, and to take into account issues of reverse causality and unobserved heterogeneity of individuals, in next Section we use data of housework time included in the BHPS to test the consistency of the results obtained in this Section.

\section{The British Household Panel Survey}

The British Household Panel Survey (BHPS) is the longest longitudinal survey of households in the UK, starting in $1991 .^{13}$ The original sample members, including their children once they turn 16, together with any partners, are interviewed annually in subsequent years in order to maintain the representativeness of the sample. As most household surveys, the BHPS collects key information on changes in family

\footnotetext{
${ }^{13}$ The last wave of the BHPS was conducted in 2008. From 2009 onwards, the BHPS was merged into the new UK Household Longitudinal Survey (UKHLS), also known as Understanding Society.
} 
composition, education, labour market experience, individual earnings, and family incomes and benefit receipts. However, the BHPS also asks all adults in all but the first wave, the number of housework hours per week. ${ }^{14}$ Another important feature for our paper is that the BHPS ask gender role attitudes of all adults aged 16 and above in oddnumbered waves. Specifically, respondents are asked if they personally agree or disagree (on a 5-point scale) with the following statement about family life: "A husband's job is to earn money; a wife's job is to look after the home and family”.

\subsection{Sample selection}

We construct a sample of young people aged 16-18, who are living with both parents aged 60 or below, in all waves. ${ }^{15}$ This is supplemented by the Youth Survey sample of 11-15 year olds living with both parents, available from Waves 12-18. Note that for the latter sub-sample, the youth housework information is categorical (don't do/less than 1, $1-3$, 4-6, or 7 or more per week). In our analysis, we will focus on the 16-18 year youth sample which has continuous measure of housework, while also look at the extensive margin of housework for the pooled sample of 11-18 year olds. ${ }^{16}$

Figure 4 shows the mean daily housework hours of the child, the father and the mother, for boys and girls separately. ${ }^{17}$ While boys aged 16-18 only spend 0.29 hours per day on housework, their female counterpart spend 0.45 hours, or $54 \%$ more time on household chores. Fathers of boys spend 0.82 hours per day on housework whereas fathers of girls only spend 0.74 hours. The gap of 0.08 hour is statistically significant at the $1 \%$ level. In contrast, there is no statistical significant difference in mother's housework hours by the child's gender, with a mean of about 2.92 hours per day. There are $30.3 \%$, or twice as any boys as there are girls, who do no housework. Fathers of boys are two percentage points less likely to be doing no housework at all. With a sample mean of 0.118 , this gap is statistically significant at the $5 \%$ level. On the other hand, only $0.5 \%$ of mothers do no housework, with no statistical significance across the

\footnotetext{
${ }^{14}$ The key question for this paper is "About how many hours do you spend on housework in an average week, such as time spent cooking, cleaning and doing the laundry?”. Although the BHPS asks who is mainly responsible among spouses for grocery shopping, cooking, cleaning/hovering, washing and ironing, and looking after children aged 12 or under, there is no breakdown by hours.

${ }^{15}$ We exclude cases where the mother is aged under 25.

${ }^{16}$ To the extent that 16-18 year olds might round up 0.50-0.99 hour per week of housework, we might be slightly over-estimating the incidence of not doing housework at all among 11-15 year olds.

${ }^{17}$ To facilitate comparison with the MTUS results, we have converted weekly housework hours to daily.
} 
gender of the child. Table 3 present summary statistics of key variables, by subsamples. It is clear that children are more likely to do any housework as they get older. Consistent with the traditional household division of labour, mothers do more housework per day than fathers. Overall, the BHPS sample is broadly comparable to the UK MTUS sample in terms of characteristics.

\subsection{Estimation results}

In the first two columns of Table 4, we present the OLS and FE estimates of the conventional intergenerational mobility model of housework behaviour, using the same specification as for Table $1 .^{18}$ Again, we add unity to daily housework hours before taking logs to allow for zero observations. OLS results suggest that a child's housework time is negatively correlated with that of the mother, although this correlation is insignificant. On the other hand, the positive effect of the father is not only statistically significant at the $1 \%$ level, but also non-negligible in sizes - a $10 \%$ increase in the father's housework time increases the child's time devoted to housework by $0.75 \%$.

When we allow for time-invariant unobservable heterogeneity which would bias cross-sectional estimates, the positive effect of the father remains significant at $5 \%$, although the size of the effect is reduced by about two-fifths. This implies that although selection explains a significant proportion of the positive effect of fathers found in cross-sectional studies, we should not dismiss this relationship as spurious. ${ }^{19}$

Columns 3 and 4 of Table 4 focus on the extensive margin of the child's housework, using the pooled sample of 11-18 year olds. The pattern is broadly consistent with the findings based on continuous housework measure. While the probability of the child doing any housework is positively correlated with that of the father, and negatively correlated with that of the mother in the OLS specification, the latter effect vanishes altogether in the FE model. On the other hand, although the size of the positive effect of father's housework time is reduced by about $15 \%$ in the FE, it remains significant at the $5 \%$ level.

The robustness of a significant effect for fathers' housework time, but not for mothers, in FE specifications is a significant finding which sheds new light on the

\footnotetext{
${ }^{18}$ Given BHPS’s long time span, we additionally control for a linear time trend.

${ }^{19}$ When we run FE for boys and girls separately, the coefficients on father's housework are virtually the same at 0.045 , and significant at the $10 \%$ level.
} 
intergenerational mobility of housework behaviour studies which are plagued by the inability to make causal inferences with time-use data. ${ }^{20}$

However, one might still be concerned with the possibility of endogeneity bias induced by time-variant unobservable heterogeneity or reverse causation. In the following, we will pursue an Instrumental Variable (IV) estimation strategy using lagged responses to the gender role attitudes questions and lagged labour supply, by either the father or the mother. Note the size of the IV sample will be roughly halved due to the fact that the gender role attitudes questions were only asked in odd-numbered waves.

In our IV estimation, we only allow father's housework time to be endogenous. ${ }^{21} \mathrm{We}$ construct a very simple binary measure which captures an egalitarian (i.e. nontraditional) gender role attitude: it is equal to one if the respondent either disagrees or strongly disagrees with the statement that a husband's job is to earn money while a wife's job is to look after the home and family. To get around the possible simultaneity problem of housework and gender role attitudes, we only use lagged attitudes. An additional IV is based on the lagged weekly working hours of either parent. The exogeneity condition requires that the instrument does not have a direct effect on the child’s housework - the outcome variable. Given that we have two instruments for one endogenous variable, we can test this directly using the over-identification test.

Table 5 presents the IV estimates. The first-stage estimates of the IVs in the bottom panel show that both instruments are statistically significant individually at $1 \%$ in all but one case where it is significant at 5\%, in explaining the variation in father's housework. Disagreeing with the traditional view of domestic division of labour by either parent has a large positive effect on the father's housework time in the following year, regardless of the subsample. As expected, an increase in the father's labour market work decreases his housework time in the following year, while an increase in the mother's housework time has the opposite effect, all else being equal.

The second-stage estimates in the upper panel suggest that father's housework

\footnotetext{
${ }^{20}$ Our results are also robust to the alternative functional form of housework time ratio. The corresponding coefficients on the ratio of father to mother housework time in the child to mother housework time ratio equations are 0.109 and 0.093 for OLS and FE specifications, respectively, and both are statistically significant at the $1 \%$ level.

${ }^{21}$ The exogeneity of mother's housework time is a quite reasonable assumption, given the traditional domestic division of labour. When measured in logs, mothers' housework has a much higher mean but a significantly lower standard deviation. Moreover, only $0.5 \%$ of mothers do no housework in our sample, compared to $12.8 \%$ of fathers.
} 
induced by his own gender role attitude and weekly working hours in the previous wave does not have a significant effect on the child's housework time. Interestingly, when the variation in father's housework time is induced by the lag of the mother's gender role attitude and her working hours in Column 2, it becomes significant at the $1 \%$ level. When we look the extensive margin of child's housework using the full sample, father's housework is again insignificant in Column 3 when driven by his own gender role attitude or working hour, but large and statistically significant at the $1 \%$ in Column 4 when driven by the corresponding measures of the mother. ${ }^{22}$

The diagnostic tests reported strongly support the validity of the instruments. The Ftests of excluded instruments all report an F-statistic well above the threshold of 10, indicating that we do not have a weak instrument problem in any of the specifications. Moreover, the Hansen $\mathrm{J}$ statistics all fail to reject the exogeneity of the instruments, with p-values well above the conventional threshold levels.

The results are consistent with a father role model story, in that parents holding more liberal (or non-traditional) gender role attitudes affect the housework behavior of their children by setting good examples themselves. This implies that even though fathers' contribution to housework might be quantitatively less important than that by mothers', it nevertheless serves a good role model for the housework behavior of the children. However, the fact that the effect of the father is only significant when it is driven by mother's gender role attitudes and actual labour supply hints on the role of intrahousehold bargaining of housework (and perhaps market work) between partners.

\subsection{Heterogeneous effects}

Table 6 checks for evidence of heterogeneous effect of father's housework time with respect to mother's employment status and educational qualifications. To save space, we only present the coefficients on the log of father and mother's housework time, on both housework outcomes of the child, in FE and IV specifications only. For the latter, we only instrument on the mother's gender role attitudes and labour supply in the previous wave, as in columns (2) and (4) of Table 5.

As might be expected, the results in Tables 4 and 5 are driven by mothers in work

\footnotetext{
${ }^{22}$ The pattern holds when we look at boys and girls separately. However, the IV estimates are not statistically significant at the $10 \%$ for boys; while for girls, they are significant at $1 \%$ for both model (2) and model (4).
} 
and/or mothers without higher educational qualifications. One possible explanation is that there is relatively little variation in either the observed parental housework time or in the values of the instruments (i.e. egalitarian gender role attitudes) among households where the mother is not working or where the mother has higher educational qualifications. It is by no coincidence that these represent the two extremes of family types along the spectrum of egalitarian gender role attitudes - the former the traditional male breadwinner type and the latter the modern family type characterised by high education and labour force participation of the mother. ${ }^{23}$

\section{Conclusions}

Despite that inter-generational mobility has been an active research area in economics, there is still much work to do to identify how family issues operate and impact on inequality between generations. This paper attempts to bridge this gap by analyzing inter-generational transmission of behaviors at home with respect to time dedicated to housework.

Using data from the Multinational Time Use Study for the UK, we find positive correlations between parents' and children's housework time, indicating that the more time parents devote to housework, the more time their children do the same. Considering different types of households, depending on the labor status and educational level of the mother, we find that the relationship between fathers and children's housework time is larger in households where the mother does not work, and we find that the positive correlation between fathers and children's housework time applies to all households independently of the educational level of the mother, while mothers' time in housework is only statistically significant in households where the mother has university education. Overall, the evidence points towards fathers' housework time having a direct effect on the housework of their children, while the effect of mother's housework time is not so clear cut.

Using data from the British Household Panel Survey to take into account issues of reverse causality and unobserved heterogeneity, we find that only fathers' housework time appears to have a statistically significant effect. The IV estimates fully support the

\footnotetext{
${ }^{23}$ Our IV results still hold, and indeed become stronger, when we exclude families with the youngest child aged 12 or under (results available upon request). This implies that our findings are not driven by the differential parental input into childcare.
} 
FE estimates and suggest that father's housework induced by his partner's nontraditional gender role attitudes towards domestic division of labour and her actual labour supply in the previous wave, has a large and significant effect on children's housework time. The effects also turn out to be more pronounced for mothers in work and/or mothers without higher educational qualifications.

Our results may be helpful for targeting public policies towards greater gender equality. In particular, and given the reported gender gap in housework time in the UK (Gimenez-Nadal and Sevilla, 2012), policies aimed at increasing the participation of fathers in housework may foster a greater gender equality in housework time in the future. This issue is important because adolescents and young people have been identified as target groups for policies to eliminate gender inequality (United Nations Millennium Project, 2010). Ignoring such effects may lead to the suboptimal design or use of these policies. 


\section{REFERENCES}

Aguiar, M., Hurst, E., 2007. Measuring trends in leisure: the allocation of time over five decades. Quarterly Journal of Economics 122, 969-1006.

Akerlof G.A., Kranton, R.E., 2000. Economics and Identity. Quarterly Journal of Economics 115, 715-753.

Álvarez, B., Miles, D., 2003. Gender Effects on Housework Allocation: Evidence from Spanish Two-Earner Couples. Journal of Population Economics 16, 227-42.

Álvarez, B., Miles, D., 2012. Exploring the relationship between parents’ and children’s housework time in Spain. Review of Economics of the Household 10, 229-318.

Altonji, J.G., Hayashi, F., Kotlikoff, L.J., 1992. Is the extended family altruistically linked? Direct evidence using micro data. American Economic Review 82, 11771198.

Anger, S. 2012. Intergenerational transmission of cognitive and noncognitive skills. In: Ermisch, J., Jäntti, M., Smeeding, T.M., (Eds.), From parents to children. The intergenerational transmission of advantage, New York, Russell Sage Foundation, pp. 393-421.

Anger, S., Heineck, G., 2010. Do Smart Parents Raise Smart Children? The Intergenerational Transmission of Cognitive Abilities. Journal of Population Economics 23, 1105-1132.

Auspurg, K., Iacovou, M., Nicoletti, C., 2014. Housework share between partners, Experimental evidence on gender identity. University of York Discussion Papers in Economics No. 14/20.

Ayalew, T., 2005. Parental Preference, Heterogeneity, Human Capital Inequality. Economic Development and Cultural Change 53, 381-407.

Baxter, J., Western, M., 1998. Satisfaction with Housework: Examining the Paradox. Sociology 32, 101-120.

Becker, G.S., 1965. A Theory of the Allocation of Time. Economic Journal 75, 493517

Becker, G.S., 1981. A Treatise on the Family. Cambridge: Harvard University Press.

Becker, G.S., Barro, R.J., 1988. A reformulation of the economic theory of fertility. 
Quarterly Journal of Economics 103, 1-25.

Becker, G.S., Tomes, N., 1976. Child Endowments and the Quantity and Quality of Children. Journal of Political Economy 84, 143-162.

Behrman, J.R., Pollak, R.A., Taubman, P., 1982. Parental Preferences and Provision for Progeny. Journal of Political Economy 90, 52-73.

Behrman, J.R., Rosenzweig, M.R. , Taubman, P., 1994. Endowments and the Allocation of Schooling in the Family and in the Marriage Market: The Twins Experiment. Journal of Political Economy 102, 1131-1174.

Berrington, A., Hu, Y., Smith, P.W.F., Sturgis, P., 2008. A graphical chain model for reciprocal relationships between women's gender role attitudes and labour force participation. Journal of the Royal Statistical Society Series A 171, 89-108.

Bianchi, S., Milkie, M., Sayer, L., Robinson, J.P., 2000. Is anyone doing the housework? Trends in the gender division of household labor. Social Forces 79, 191-228.

Bittman, M., England, P., Folbre, N., Sayer, L., Matheson, G., 2003. When Does Gender Trump Money? Bargaining and Time in Household Work. American Journal of Sociology 109, 186-214.

Black, S.E., Devereux, P.J., 2011. Recent developments in intergenerational mobility,” In: Card, D., Ashenfelter, O., (Eds). Handbook of Labor Economics, Vol 4b, Elsevier, pp. 1487-1541.

Bonke, J., 2005. Paid work and unpaid work: Diary information versus questionnaire information. Social Indicators Research 70, 349-368.

Brines, J., 1994. Economic Dependency, Gender, and the Division of Labor at Home. American Journal of Sociology 100, 652-688

Bulte, E.H., Horan, R.D., 2011. Intergenerational transmission of preferences. Economics Letters 112, 85-87.

Carlsson, F., Lampi, E., Li, W., Martinsson, P., 2014. Subjective well-being among preadolescents and their parents: Evidence of intergenerational transmission of well-being from urban China. Journal of Socio-Economics 48, 11-18.

Casas, F., Coenders, G., Cummins, R.A., Gonzalez, M., Figuer, C., Malo, S., 2008. 
Does subjective well-being show a relationship between parents and their children? Journal of Happiness Studies 9, 197-205.

Cassidy, M.L., Warren, B.O., 1996. Family Employment Status and Gender Role Attitudes: A Comparison of Women and Men College Graduates. Gender and Society $10,312-322$.

Cigno, A., 1993. Intergenerational transfers without altruism. Family, market and state. European Journal of Political Economy 9, 508-518.

Cigno, A., Giannelli, G.C., Rosati, F.C., 1998. Voluntary transfers among Italian households: altruistic and non-altruistic explanations. Structural Change and Economic Dynamics 9, 435-451.

Clair, A., 2012. The relationship between parent's subjective well-being and the life satisfaction of their children in Britain. Child Indicators Research 5, 631-650.

Cohen, P.N., 1998. Replacing Housework in the Service Economy. Gender and Society 12, 219-232.

Cohen, P.N., 2004. The Gender Division of Labor: 'Keeping House’ and Occupational Segregation in the United States. Gender and Society 18, 239-252.

Connelly, R., Kimmel, J., 2007. Determinants of Mothers’ Time Choices in the United States: Caregiving, Leisure, Home Production, and Paid Work. Journal of Human Resources 42, 643-681.

Connelly, R., Kimmel, J., 2009. Spousal Influences on Parents' Non-Market Time Choices. Review of Economics of the Household 7, 361-394.

Corak, M., 2013. Income inequality, equality of opportunity, and intergenerational mobility. Journal of Economic Perspectives 27, 79-102.

Cox, D., 1990. Intergenerational Transfers and Liquidity Constraints. Quarterly Journal of Economics 105, 187-217.

Cox, D., Rank, M., 1992. Inter-Vivos Transfers and Intergenerational Exchange. Review of Economics and Statistics 74, 305-314.

Croft, A., Schmader, T., Block, K., Baron, A. S., 2014. The Second Shift Reflected in the Second Generation: Do Parents' Gender Roles at Home Predict Children's Aspirations? Psychological Science 25, 1418-1428. 
Crompton, R., Brockmann, M., Lyonette, C., 2005. Attitudes, women’s employment and the domestic division of labour. Work, Employment and Society 19, 213-233.

Datar, A., Kilburn, M.R., Loughran, D.S., 2010. Endowments and parental investements in infancy and early childhood. Demography 47, 145-162.

Dohmen, T., Falk, A., Huffman, D., Sunde, U., 2012. The intergenerational transmission of risk and trust attitudes. Review of Economic Studies 79, 645-677.

Edgeworth, F., 1881. Mathematical Psychics: An Esssay of the Application of Mathematics to the Moral Sciences. C. Kegan Paul and Co. London.

Evertsson, M., Nermo, M., 2004. Dependence within Families and the Division of Labor: Comparing Sweden and the United States. Journal of Marriage and Family 66, 1272-86.

Farré, L., Vella, F., 2013. The intergenerational transmission of gender role attitudes and its implications for female labor force participation. Economica 80, 219-247.

Fisher K, Gershuny, J., Gauthier, A., 2011. Multinational Time Use Study: User’s Guide and Documentation. http://www.timeuse.org/files/cckpub/858/mtus-userguide-r4.pdf. Accessed 1 September 2012.

Foster, G., Kalenkoski, C., 2013. Tobit or OLS? An empirical evaluation under different diary window lengths. Applied Economics 45, 2994-3010.

Frazis, H., Stewart, J., 2012. How to Think About Time-Use Data: What Inferences Can We Make About Long- and Short-Run Time Use from Time Use Diaries? Annals of Economics and Statistics 105/106, 231-246.

Gershuny, J., 2000. Changing times, work and leisure in post industrial society. Oxford: Oxford University Press.

Gershuny, J.I., 2009. Veblen in Reverse: Evidence from the Multinational Time-Use Archive. Social Indicators Research 93, 37-45.

Gershuny, J.I., 2012. Too Many Zeros: A Method for Estimating Long-term Time-use from Short Diaries. Annals of Economics and Statistics 105/106, 247-270.

Giménez-Nadal, J.I., Molina, J.A., 2013. Parents' education as determinant of educational childcare time. Journal of Population Economics 26, 719-749.

Gimenez-Nadal, J.I., Molina, J.A., Sevilla-Sanz, A., 2012. Social Norms, Partnerships 
and Children. Review of Economics of the Household 10, 215-236.

Giménez-Nadal, J.I., Sevilla, A., 2012. Trends in time allocation: A cross-country analysis. European Economic Review 56, 1338-1359.

Greene, W., 2004. Fixed Effects and Bias Due to the Incidental Parameters Problem in the Tobit Model. Econometric Reviews 23, 125-147.

Griliches, Z., 1979. Sibling Models and Data in Economics: Beginnings of a Survey. Journal of Political Economy 87, S37-S64.

Grønhoj, A., Thøgersen, J., 2009. Like father, like son? Intergenerational transmission of values, attitudes, and behaviours in the environmental domain. Journal of Environmental Psychology 29, 414-421.

Hamermesh, D., Lee, J., 2007. Stressed out in four continents: time crunch or Yuppie Kvetch? Review of Economics and Statistics 89, 374-383.

Hendricks, L., 2007. The intergenerational persistence of lifetime earnings. European Economic Review 51, 125-144.

Hersch, J., Stratton, L., 2002. Housework and Wages. Journal of Human Resources 37, 217-229.

Holmlund, H., Lindahl, M., Plug, E., 2011. The causal effects of parent's education on children' schooling: a comparison of estimation methods. Journal of Economic Literature 49, 615-651.

Johnston, D.W., Schurer, S., Shields, M.A., 2014. Maternal gender role attitudes, human capital investment, and labour supply of sons and daughters. Oxford Economic Papers 66, 631-659.

Juster, T. Stafford, F. 1985. Time, Goods, and Well-Being. Ann Arbor, MI. Institute for Social Research.

Kalenkoski, C., Ribar, D., Stratton, L.S., 2005. Parental Child Care in Single-Parent, Cohabiting, and Married Couples Families: Time-Diary Evidence from the United Kingdom. American Economic Review 95, 194-198.

Klevmarken, N.A., 2005. Estimates of a labour supply function using alternative measures of hours of work. European Economic Review 49, 55-73.

Kirchsteiger, G., Sebaid, A., 2010. Investments into education - Doing as the parents did. 
European Economic Review 54, 501-5016.

Lennon, M. C., Rosenfield, S., 1994. Relative Fairness and the Division of Housework: The Importance of Options. American Journal of Sociology 100, 506-531.

Mason, K.O., Czajka, J.L., Arber, S., 1976. Change in U.S. Women’s Sex Role Attitudes, 19641974. American Sociological Review 41, 573-96.

Mason, K.O., Lu, Y.H., 1988. Attitudes toward Women’s Familial Roles: Changes in the United States, 1977-1985. Gender and Society 2, 39-57.

McIntosh, J., Munk, M.D., 2009. Social class, family background, and intergenerational mobility. European Economic Review 53, 107-117.

Molina, J.A., 2013. Altruism in the household: in-kind transfers in the context of kin selection. Review of Economics of the Household 11, 309-312.

Molina, J.A., 2014. Altruism and monetary transfers in the household: inter- and intra generation issues. Review of Economics of the Household 12, 407-410.

Molina, J.A., Navarro, M., Walker, I., 2011. Intergenerational Well-Being Mobility in Europe. Kyklos 64, 253-270.

Necker, S., Voskort, A., 2014. Intergenerational transmissions of risk attitudes - A revealed preference approach. European Economic Review 65, 66-89.

Peek, C.W., Lowe, G.D., Williams, L.S., 1991. Gender and God's Word: Another Look at Religious Fundamentalism and Sexism. Social Forces 69, 1205-21.

Pitt, M.M., Rosenzweig, M.R., Hassan, M.N., 1990. Productivity, Health, and Inequality in the Intrahousehold Distribution of Food in Low-Income Countries. American Economic Review 80, 1139-56.

Robinson, J.P., 1985. The validity and reliability of diaries versus alternative time use measures. In: Juster, T., Stafford, J., (Eds.) Time, goods, and well-being. Ann Arbor, MI: The University of Michigan, pp 33-62.

Robinson, J.P., Godbey, G., 1997). Time for Life: The Surprising Ways Americans Use their Time. University Park, PA. Pennsylvania State University Press.

Roemer, J.E., 2004. Equal opportunity and intergenerational mobility: going beyond intergenerational income transition matrices,” In: Corak, M., (Ed.) Generational Income Mobility in North America and Europe, Cambridge University Press.

Rosenzweig, M.R., Schultz, T.P., 1982. Market Opportunities, Genetic Endowments, and Intrafamily Resource Distribution: Child Survival in Rural India. American Economic 
Review 72, 803-815.

Rosenzweig, M.R., Wolpin, K.I., 1988. Heterogeneity, Intrafamily Distribution, and Child Health. Journal of Human Resources 23,: 437-461.

Schober, P., Scott, J., 2013. Maternal employment and gender role attitudes: dissonance among British men and women in the transition to parenthood. Industrial Relations and Labor 26, 514-530.

Sevilla, A., 2010. Household división of labor and cross-country differences in household formation rates. Journal of Population Economics 23, 225-249.

Sevilla, A., Gimenez-Nadal, J.I., Fernandez, C., 2010. Gender Roles and the Division of Unpaid Work in Spanish Households. Feminist Economics 16, 137-184.

Smith, A., 1759. The Theory of Moral Sentiments. Printed for A. Millar, in the Strand; and A. Kincaid and J. Bell, in Edinburgh.

Solaz A., Wolff, F.C., 2015. Intergenerational transmission of domestic work and gender roles. Annals of Economics and Statistics, forthcoming.

Solon, G., 1999. Intergenerational mobility in the labor market,” In: Ashenfelter, O., Card, D., (Eds.) Handbook of Labor Economics, Volume 3, Amsterdam: Elsevier Science, pp. 1761-1800.

Solon, G., 2002. Cross-country differences in intergenerational earnings mobility. Journal of Economic Perspectives 16, 56-66.

Solon, G., 2004. A model of intergenerational mobility variation over time and place,” In: Corak, M., (Ed.) Generational Income Mobility in North America and Europe, Cambridge University Press.

Stella, L., 2013. Intergenerational transmission of human capital in Europe: evidence from SHARE. IZA Journal of European Labor Studies, 2-13.

Tallichet, S.E., Willits, F.K., 1986. Gender Role Attitude Change of Young Women: Influential Factors from a Panel Study. Social Psychology Quarterly 49, 219-27.

Thornton, A., Freedman, D., 1979. Changes in Sex Role Attitudes of Women, 1962-1977. American Sociological Review 44, 831-42

Tobin, J., 1958. Estimation of relationships for limited dependent variables. Econometrica 26, 24-36.

Tsou, M.W., Liu, J.T., Hammitt, J.K., 2012. The intergenerational transmission of education: Evidence from Taiwanese adoptions. Economics Letters 115, 134-136. 
United Nations Millennium Project. 2010.

Wilhelm, M.O., Brown, E., Rooney, P.M., Steinberg, R., 2008. The intergenerational transmission of generosity. Journal of Public Economics 92, 2146-2156.

Winkelmann, R., 2005. Subjective Well-Being and the Family: Results from an Ordered Probit Model with Multiple Random Effects. Empirical Economics 30, 749-761.

Kan, M.Y., 2008. Measuring Housework Participation: The Gap Between "Stylised" Questionnaire Estimates and Diary-Based Estimates. Social Indicators Research 86, 381400. 
Figure 1. Mother's share of housework and market work by education level, BHPS sample

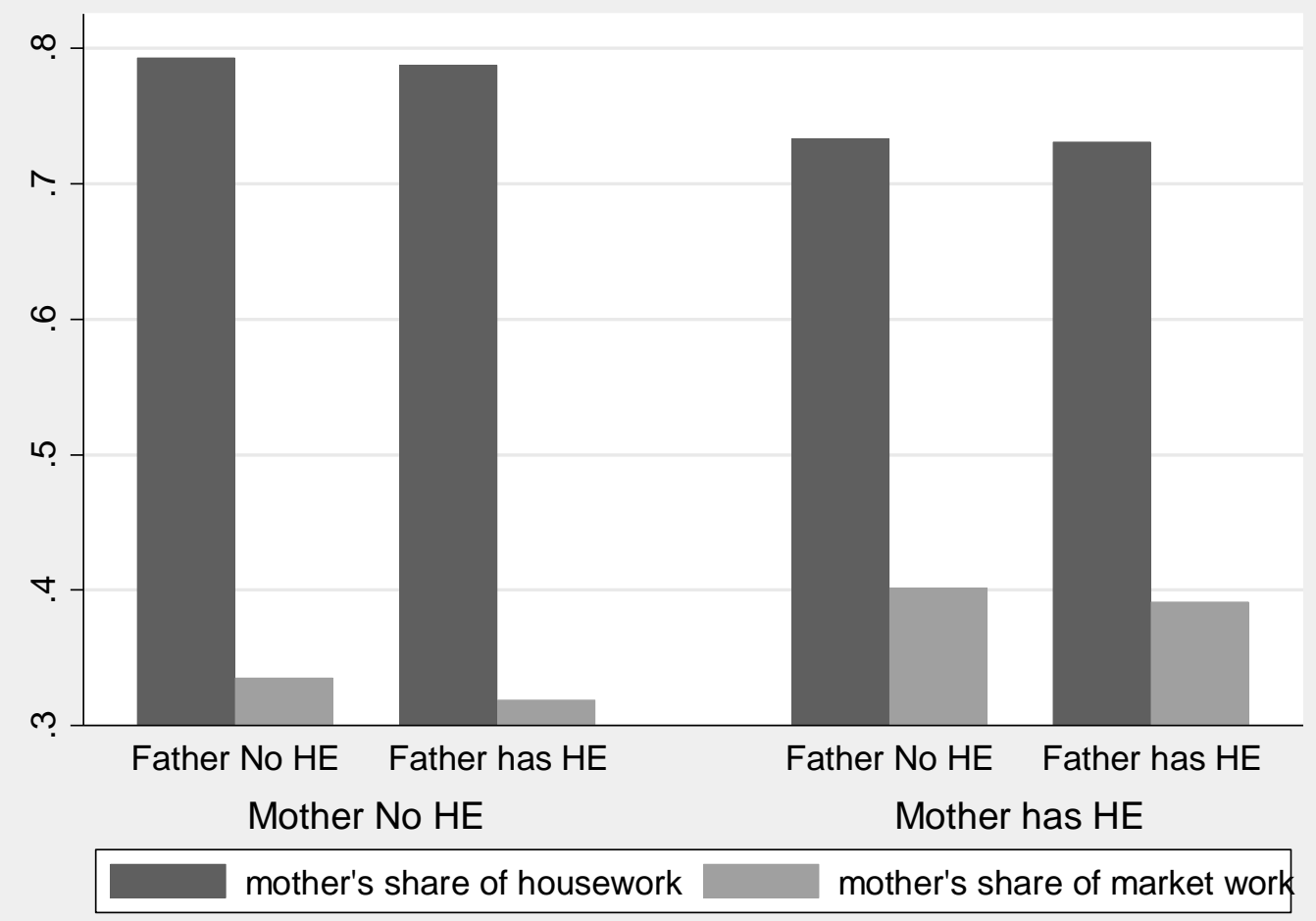


Figure 2. Distribution of housework time

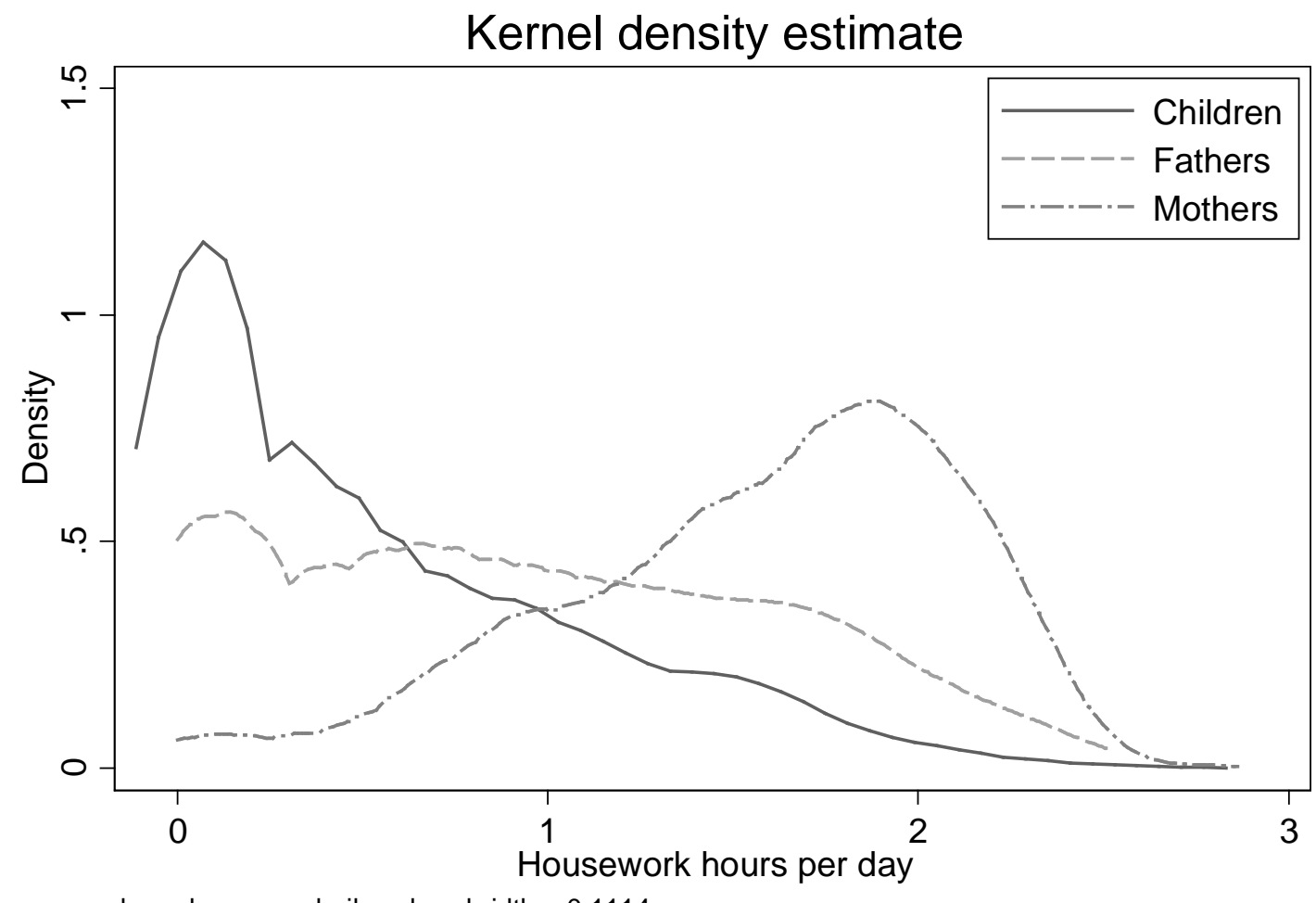

kernel $=$ epanechnikov, bandwidth $=0.1114$

Note: Sample consists of individuals who are between 11 and 18 years old, who are reported as being a child in the household, and living with two heterosexual parents from the UK. We include parents of those children. Housework includes the total time devoted to the following activities: "cook, wash up", "housework", "odd jobs”, "shopping” and "domestic travel”, and is measured in hours per day. 
Figure 3. Mean time devoted to non-market work, parents and children
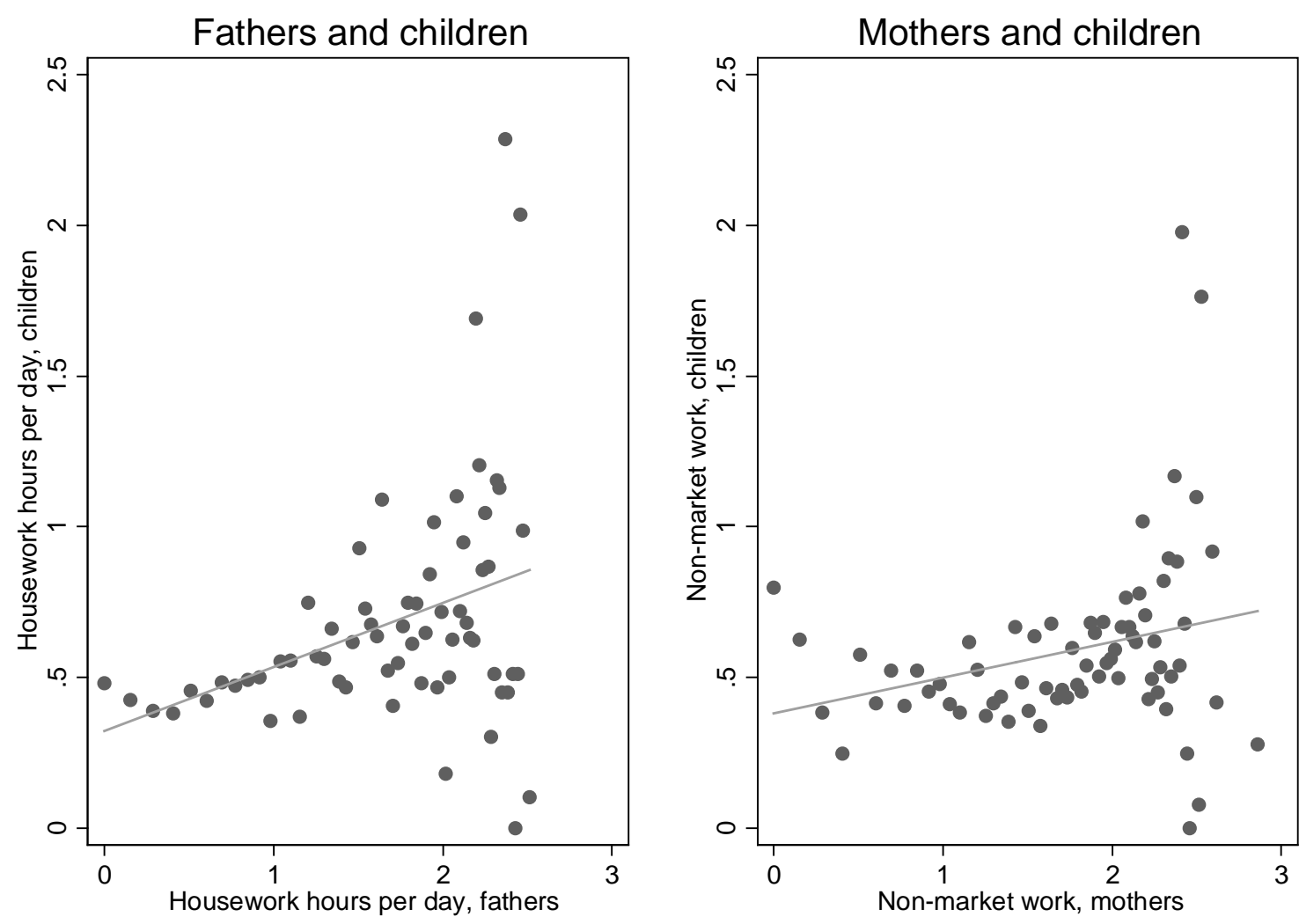

Note: Sample consists of individuals who are between 11 and 18 years old, who are reported as being a child in the household, and living with two heterosexual parents from the UK. We include fathers of those children. Housework includes the total time devoted to the following activities: "cook, wash up", "housework", "odd jobs", "shopping” and "domestic travel", and is measured in hours per day. 
Figure 4. Time devoted to housework by fathers, mothers and children, by gender of the child

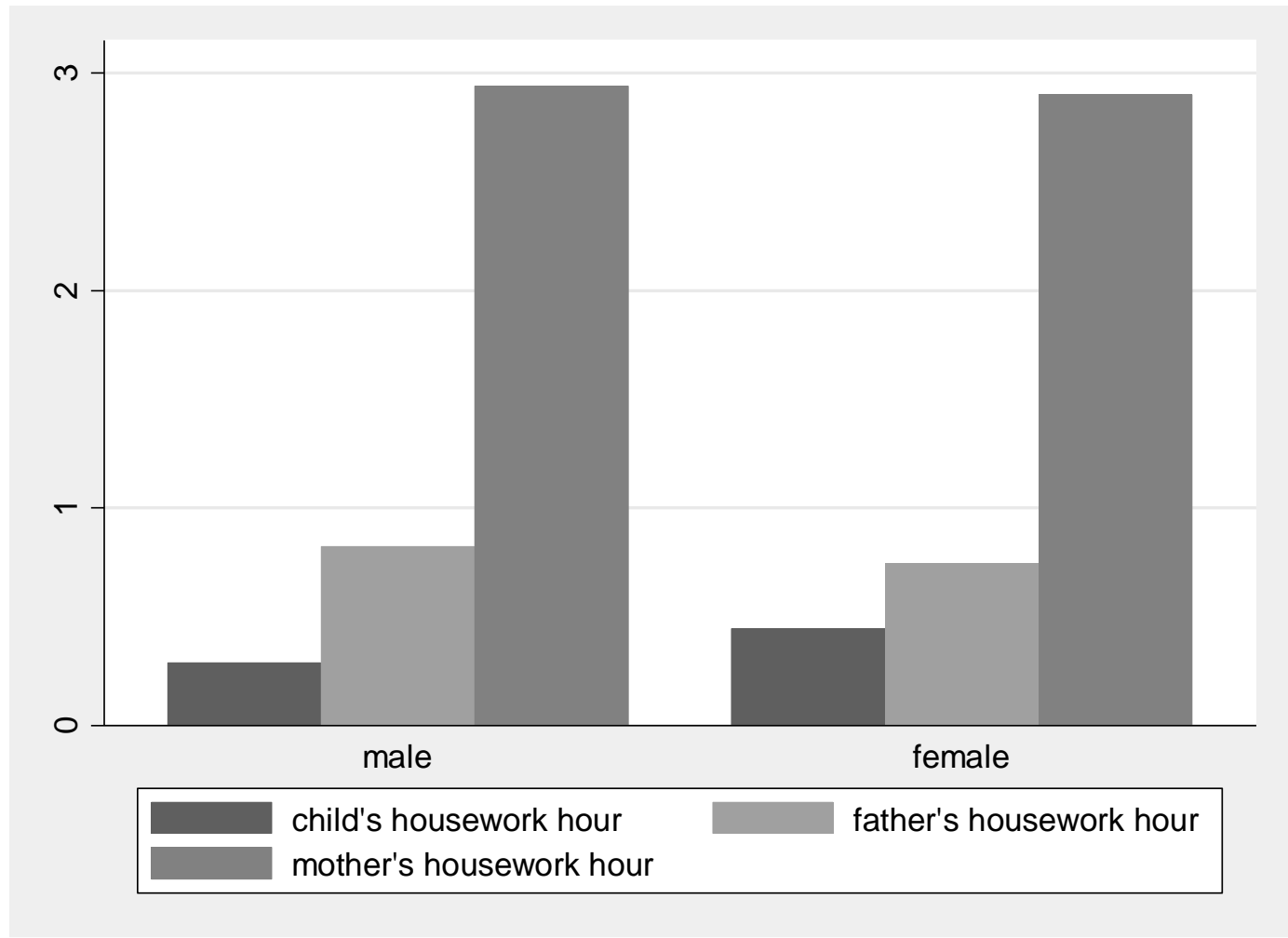

Note: Sample consists of individuals aged 16-18, who are living with both parents aged 60 or below, in all waves of the BHPS, Housework time refers to average hours per day spent on housework, such as time spent cooking, cleaning and doing the laundry. 
Table 1: Analysis of the United Kingdom Time Use Survey (2000)

\begin{tabular}{|c|c|c|c|c|c|}
\hline & \multirow{2}{*}{$\begin{array}{c}\begin{array}{c}\text { Sample } \\
\text { means }\end{array} \\
(1)\end{array}$} & \multicolumn{2}{|c|}{$\begin{array}{c}\text { Log of } \\
\text { (child's daily } \\
\text { housework time+1) }\end{array}$} & \multicolumn{2}{|c|}{$\begin{array}{c}\text { Child/mother } \\
\text { housework ratio }\end{array}$} \\
\hline & & $(2)$ & (3) & $(4)$ & $(5)$ \\
\hline \multirow[t]{2}{*}{ Child's housework } & 0.527 & - & - & - & - \\
\hline & $(0.553)$ & - & - & - & - \\
\hline \multirow[t]{2}{*}{ Father's housework time } & 0.908 & $0.106^{* * *}$ & $0.157 * * *$ & - & - \\
\hline & $(0.676)$ & $(0.023)$ & $(0.029)$ & - & - \\
\hline \multirow[t]{2}{*}{ Mother's housework } & 1.559 & $0.075^{* * *}$ & $0.104 * * *$ & - & - \\
\hline & $(0.547)$ & $(0.029)$ & $(0.036)$ & - & - \\
\hline \multirow[t]{2}{*}{ Male } & 0.521 & $-0.193^{* * *}$ & - & $-0.195 * * *$ & - \\
\hline & $(0.500)$ & $(0.028)$ & - & $(0.054)$ & - \\
\hline \multirow[t]{2}{*}{ Age of respondent } & 14.298 & $0.018^{*}$ & - & $0.031 * *$ & - \\
\hline & $(2.245)$ & $(0.010)$ & - & $(0.015)$ & - \\
\hline \multirow[t]{2}{*}{ Student } & 0.872 & 0.049 & - & -0.153 & - \\
\hline & $(0.334)$ & $(0.064)$ & - & $(0.137)$ & - \\
\hline \multirow[t]{2}{*}{ Unemployed } & 0.029 & 0.172 & - & -0.025 & - \\
\hline & $(0.167)$ & $(0.138)$ & - & $(0.152)$ & - \\
\hline \multirow[t]{2}{*}{ Working part-/full-time } & 0.189 & $-0.119 *$ & - & $-0.138 *$ & - \\
\hline & $(0.392)$ & $(0.061)$ & - & $(0.080)$ & - \\
\hline \multirow[t]{2}{*}{ Father's secondary education } & 0.360 & 0.017 & - & -0.014 & - \\
\hline & $(0.480)$ & $(0.038)$ & - & $(0.074)$ & - \\
\hline \multirow[t]{2}{*}{ Mother's secondary education } & 0.352 & 0.035 & - & 0.019 & - \\
\hline & $(0.478)$ & $(0.036)$ & - & $(0.079)$ & - \\
\hline \multirow[t]{2}{*}{ Father's university education } & 0.278 & -0.034 & - & 0.030 & - \\
\hline & $(0.448)$ & $(0.042)$ & - & $(0.100)$ & - \\
\hline \multirow[t]{2}{*}{ Mother's university education } & 0.271 & -0.005 & - & -0.069 & - \\
\hline & $(0.444)$ & $(0.041)$ & - & $(0.079)$ & - \\
\hline \multirow[t]{2}{*}{ Father's age } & 44.521 & 0.000 & - & -0.001 & - \\
\hline & $(6.837)$ & $(0.003)$ & - & $(0.006)$ & - \\
\hline \multirow{2}{*}{ Mother's age } & 42.232 & 0.002 & - & -0.005 & - \\
\hline & $(5.752)$ & $(0.004)$ & - & $(0.006)$ & - \\
\hline \multirow{2}{*}{ Father working part-/full-time } & 0.847 & 0.025 & - & 0.040 & - \\
\hline & $(0.360)$ & $(0.048)$ & - & $(0.050)$ & - \\
\hline \multirow[t]{2}{*}{ Mother working part-/full-time } & 0.753 & $0.093 * *$ & - & $0.119 * *$ & - \\
\hline & $(0.432)$ & $(0.039)$ & - & $(0.049)$ & - \\
\hline \multirow[t]{2}{*}{ Household size } & 4.579 & 0.004 & - & -0.008 & - \\
\hline & $(1.184)$ & $(0.016)$ & - & $(0.019)$ & - \\
\hline \multirow[t]{2}{*}{ Number of children $<18$} & 11.181 & -0.002 & - & -0.003 & - \\
\hline & $(4.182)$ & $(0.006)$ & - & $(0.007)$ & - \\
\hline \multirow[t]{2}{*}{ Household owns dwelling } & 0.808 & 0.056 & - & $0.112^{*}$ & - \\
\hline & $(0.394)$ & $(0.041)$ & - & $(0.060)$ & - \\
\hline Father/mother housework ratio & 0.883 & - & - & $0.245^{* * *}$ & $0.263^{* * *}$ \\
\hline & $(2.417)$ & - & - & $(0.031)$ & $(0.013)$ \\
\hline Constant & - & 0.151 & $0.429 * * *$ & 0.232 & $0.318 * * *$ \\
\hline & - & $(0.181)$ & $(0.072)$ & $(0.198)$ & $(0.055)$ \\
\hline Day Fixed-Effects & No & Yes & Yes & Yes & Yes \\
\hline Person Fixed Effects & No & No & Yes & No & Yes \\
\hline Observations & 2,703 & 1,771 & 1,771 & 1,747 & 1,747 \\
\hline R-Squared & - & 0.118 & 0.075 & 0.298 & 0.339 \\
\hline
\end{tabular}


Table 2: Analysis of the United Kingdom Time Use Survey (2000), heterogeneous effects

\begin{tabular}{|c|c|c|c|c|c|}
\hline \multirow[t]{3}{*}{ Dependent variable } & \multicolumn{5}{|c|}{$\begin{array}{c}\text { Log of } \\
\text { (child's daily housework time+1) }\end{array}$} \\
\hline & (1) & $(2)$ & (3) & (4) & (5) \\
\hline & Mother working & $\begin{array}{l}\text { Mother non- } \\
\text { working }\end{array}$ & $\begin{array}{c}\text { Mother primary } \\
\text { educ. }\end{array}$ & $\begin{array}{c}\text { Mother second } \\
\text { educ. }\end{array}$ & Mother univ educ. \\
\hline \multirow[t]{2}{*}{ Father's housework } & $0.093 * * *$ & $0.162 * * *$ & $0.114^{* * *}$ & $0.077 * *$ & $0.115^{* *}$ \\
\hline & $(0.026)$ & $(0.045)$ & (0.039) & $(0.039)$ & $(0.046)$ \\
\hline \multirow[t]{2}{*}{ Mother's housework } & $0.066^{*}$ & 0.089 & 0.051 & 0.000 & $0.204^{* * *}$ \\
\hline & $(0.034)$ & $(0.055)$ & $(0.042)$ & $(0.053)$ & $(0.056)$ \\
\hline Observations & 1,323 & 448 & 611 & 630 & 530 \\
\hline R-Squared & 0.109 & 0.174 & 0.132 & 0.117 & 0.225 \\
\hline
\end{tabular}


Table 3: BHPS Summary Statistics, by sub-sample

\begin{tabular}{|c|c|c|c|}
\hline & $\begin{array}{c}\text { Sample of } \\
16-18 \text { children }\end{array}$ & $\begin{array}{c}\text { Sample of } \\
11-15 \text { children }\end{array}$ & Pooled sample \\
\hline Log (child's daily housework hour+1) & 0.274 & - & - \\
\hline Child doing any housework & 0.775 & 0.666 & 0.718 \\
\hline Log (father's daily housework hour+1) & 0.492 & 0.528 & 0.511 \\
\hline Log (mother's daily housework hour+1) & 1.278 & 1.231 & 1.253 \\
\hline Child male & 0.485 & 0.516 & 0.501 \\
\hline Child's age & 16.92 & 13.11 & 14.90 \\
\hline Child is student & 0.561 & 1.000 & 0.836 \\
\hline Child not in employment or education & 0.048 & 0.000 & 0.023 \\
\hline Child working full/part time & 0.253 & 0.000 & 0.119 \\
\hline Father secondary education & 0.270 & 0.283 & 0.276 \\
\hline Mother secondary education & 0.322 & 0.340 & 0.331 \\
\hline Father higher education & 0.454 & 0.522 & 0.490 \\
\hline Mother higher education & 0.363 & 0.447 & 0.407 \\
\hline Father's age & 46.74 & 42.96 & 44.73 \\
\hline Mother's age & 44.61 & 41.01 & 42.70 \\
\hline Father working full/part time & 0.875 & 0.886 & 0.881 \\
\hline Mother working full/part time & 0.774 & 0.744 & 0.758 \\
\hline Household size & 4.413 & 4.521 & 4.470 \\
\hline Number of children under 16 & 0.777 & 2.064 & 1.460 \\
\hline Household owns dwelling & 0.838 & 0.794 & 0.815 \\
\hline Wave indicator (linear time trend) & 10.76 & 14.92 & 12.97 \\
\hline Obs & 4,703 & 5,313 & 10,016 \\
\hline
\end{tabular}

Note: Sample consists of individuals aged 16-18, who are living with both parents aged 60 or below, in all waves of the BHPS, and individuals aged 11-15 year olds living with both parents, from Waves 12-18 of the Youth Survey. Housework time variables constructed from the question "About how many hours do you spend on housework in an average week, such as time spent cooking, cleaning and doing the laundry?” 
Table 4: Ordinary Least Squares (OLS) and Fixed-effects (FE) estimates, the BHPS

\begin{tabular}{|c|c|c|c|c|}
\hline \multirow[t]{3}{*}{ Dependent variable } & \multicolumn{2}{|c|}{$\begin{array}{c}\text { Log of } \\
\text { (child's daily housework time+1) }\end{array}$} & \multicolumn{2}{|c|}{ Indicator for doing any housework } \\
\hline & (1) & $(2)$ & (3) & (4) \\
\hline & OLS & FE & OLS & FE \\
\hline \multirow[t]{2}{*}{ Log of (father's daily housework time+1) } & $0.075^{* * *}$ & $0.044^{* *}$ & $0.066^{* * *}$ & $0.056^{* *}$ \\
\hline & $(0.011)$ & $(0.020)$ & $(0.012)$ & $(0.022)$ \\
\hline \multirow[t]{2}{*}{ Log of (mother's daily housework time+1) } & -0.015 & 0.002 & $-0.036^{* * * *}$ & -0.014 \\
\hline & $(0.011)$ & $(0.016)$ & $(0.012)$ & $(0.019)$ \\
\hline \multirow[t]{2}{*}{ Young Person is male } & $-0.110^{* * *}$ & - & $-0.143^{* * *}$ & - \\
\hline & $(0.007)$ & - & $(0.009)$ & - \\
\hline \multirow[t]{2}{*}{ Young Person's age } & $0.018^{* * *}$ & $-0.033^{*}$ & $0.032^{* * * *}$ & -0.006 \\
\hline & $(0.005)$ & $(0.020)$ & $(0.003)$ & $(0.022)$ \\
\hline \multirow[t]{2}{*}{ Young Person is student } & -0.017 & -0.006 & $0.108^{* * *}$ & 0.048 \\
\hline & $(0.021)$ & $(0.025)$ & $(0.031)$ & $(0.035)$ \\
\hline \multirow[t]{2}{*}{ Young Person is unemployed } & $0.097^{* * *}$ & $0.126^{* * *}$ & $0.117^{* * *}$ & $0.103^{* *}$ \\
\hline & $(0.031)$ & $(0.035)$ & $(0.040)$ & $(0.046)$ \\
\hline \multirow[t]{2}{*}{ Young Person working full/part-time } & $-0.041^{*}$ & -0.025 & 0.008 & -0.020 \\
\hline & $(0.022)$ & $(0.026)$ & $(0.032)$ & $(0.036)$ \\
\hline \multirow{2}{*}{ Father secondary education } & -0.014 & 0.040 & $0.022^{*}$ & $0.158^{* * * *}$ \\
\hline & (0.011) & $(0.068)$ & $(0.013)$ & $(0.061)$ \\
\hline \multirow[t]{2}{*}{ Mother secondary education } & -0.001 & $-0.099^{*}$ & $0.041^{* * *}$ & 0.007 \\
\hline & $(0.010)$ & $(0.051)$ & $(0.012)$ & $(0.052)$ \\
\hline \multirow[t]{2}{*}{ Father higher education } & 0.003 & -0.000 & $0.069^{* * *}$ & $0.183^{* * * *}$ \\
\hline & $(0.010)$ & $(0.051)$ & $(0.012)$ & $(0.065)$ \\
\hline \multirow[t]{2}{*}{ Mother higher education } & 0.005 & $-0.090^{* * *}$ & $0.068^{* * *}$ & -0.036 \\
\hline & $(0.010)$ & $(0.043)$ & $(0.012)$ & $(0.048)$ \\
\hline \multirow[t]{2}{*}{ Father's age } & $0.003^{* * *}$ & 0.030 & 0.002 & 0.013 \\
\hline & $(0.001)$ & $(0.019)$ & $(0.001)$ & $(0.011)$ \\
\hline \multirow[t]{2}{*}{ age at date of interview } & $-0.005^{* * *}$ & 0.026 & $-0.003^{* *}$ & -0.006 \\
\hline & $(0.001)$ & $(0.018)$ & $(0.001)$ & $(0.011)$ \\
\hline \multirow[t]{2}{*}{ Father working full/part-time } & $0.026^{*}$ & 0.029 & $0.048^{* * * *}$ & -0.001 \\
\hline & $(0.015)$ & $(0.031)$ & $(0.016)$ & $(0.032)$ \\
\hline \multirow[t]{2}{*}{ Mother working full/part-time } & 0.012 & 0.026 & 0.004 & 0.033 \\
\hline & $(0.011)$ & $(0.019)$ & $(0.012)$ & $(0.021)$ \\
\hline \multirow[t]{2}{*}{ number of people in household } & $0.026^{* * *}$ & $0.026^{*}$ & $0.029^{* * *}$ & 0.023 \\
\hline & $(0.006)$ & $(0.014)$ & $(0.006)$ & $(0.015)$ \\
\hline \multirow[t]{2}{*}{ number of children in household } & $-0.020^{* * * *}$ & -0.017 & $-0.017^{* *}$ & -0.009 \\
\hline & $(0.007)$ & $(0.015)$ & $(0.007)$ & $(0.013)$ \\
\hline \multirow[t]{2}{*}{ Household owns dwelling } & -0.008 & 0.029 & -0.013 & -0.050 \\
\hline & $(0.013)$ & $(0.040)$ & $(0.013)$ & $(0.045)$ \\
\hline \multirow[t]{2}{*}{ Wave Indicator } & $0.002^{* * *}$ & -0.002 & $-0.005^{* * *}$ & 0.021 \\
\hline & $(0.001)$ & $(0.021)$ & $(0.001)$ & $(0.027)$ \\
\hline \multirow[t]{2}{*}{ Constant } & -0.052 & $-1.873^{* *}$ & $0.141^{* * *}$ & -0.016 \\
\hline & $(0.096)$ & $(0.732)$ & $(0.072)$ & $(0.545)$ \\
\hline$R^{2}$ & 0.080 & 0.041 & 0.070 & 0.014 \\
\hline Observations (person-waves) & 4,703 & 4,703 & 10,016 & 10,016 \\
\hline
\end{tabular}


Table 5: IV estimates, the BHPS

\begin{tabular}{|c|c|c|c|c|}
\hline \multirow{2}{*}{$\begin{array}{l}\text { Dependent variable } \\
\begin{array}{l}\text { Source of instruments (lagged egalitarian gender role } \\
\text { attitudes \& lagged weekly working hours) }\end{array}\end{array}$} & \multicolumn{2}{|c|}{$\begin{array}{c}\text { Log of } \\
\text { (child's daily housework } \\
\text { time }+1 \text { ) } \\
\end{array}$} & \multicolumn{2}{|c|}{$\begin{array}{l}\text { Indicator for doing any } \\
\text { housework }\end{array}$} \\
\hline & $\begin{array}{c}(1) \\
\text { Father's own } \\
\end{array}$ & $\begin{array}{c}\text { (2) } \\
\text { Mother's }\end{array}$ & $\begin{array}{c}\text { (3) } \\
\text { Father's own } \\
\end{array}$ & $\begin{array}{c}(4) \\
\text { Mother's }\end{array}$ \\
\hline \multicolumn{5}{|l|}{ Second-stage } \\
\hline Log of (father's daily housework time+1) & $\begin{array}{l}-0.015 \\
(0.144)\end{array}$ & $\begin{array}{l}0.301^{* * *} \\
(0.110)\end{array}$ & $\begin{array}{c}0.087 \\
(0.129)\end{array}$ & $\begin{array}{l}0.377^{* *} \\
(0.157)\end{array}$ \\
\hline Log of (mother's daily housework time+1) & $\begin{array}{l}-0.050 \\
(0.039)\end{array}$ & $\begin{array}{c}0.033 \\
(0.033)\end{array}$ & $\begin{array}{l}-0.033 \\
(0.031)\end{array}$ & $\begin{array}{c}0.028 \\
(0.036)\end{array}$ \\
\hline Young Person is male & $\begin{array}{c}-0.106^{* * * *} \\
(0.011)\end{array}$ & $\begin{array}{c}-0.122^{* * * *} \\
(0.011)\end{array}$ & $\begin{array}{c}-0.136^{* * * *} \\
(0.013)\end{array}$ & $\begin{array}{c}-0.148^{* * *} \\
(0.013)\end{array}$ \\
\hline Young Person's age & $\begin{array}{l}0.013^{*} \\
(0.007)\end{array}$ & $\begin{array}{c}0.009 \\
(0.007)\end{array}$ & $\begin{array}{l}0.035^{* * * *} \\
(0.004)\end{array}$ & $\begin{array}{l}0.034^{* * *} \\
(0.004)\end{array}$ \\
\hline Young Person is student & $\begin{array}{l}-0.024 \\
(0.029)\end{array}$ & $\begin{array}{l}-0.022 \\
(0.031)\end{array}$ & $\begin{array}{l}0.116^{* * *} \\
(0.042)\end{array}$ & $\begin{array}{l}0.112^{* * *} \\
(0.043)\end{array}$ \\
\hline Young Person is unemployed & $\begin{array}{c}0.071 \\
(0.045)\end{array}$ & $\begin{array}{l}0.083^{*} \\
(0.048)\end{array}$ & $\begin{array}{c}0.056 \\
(0.059)\end{array}$ & $\begin{array}{c}0.057 \\
(0.059)\end{array}$ \\
\hline Young Person working full/part-time & $\begin{array}{l}-0.038 \\
(0.031)\end{array}$ & $\begin{array}{l}-0.028 \\
(0.032)\end{array}$ & $\begin{array}{c}0.029 \\
(0.044)\end{array}$ & $\begin{array}{c}0.030 \\
(0.045)\end{array}$ \\
\hline Father secondary education & $\begin{array}{l}-0.010 \\
(0.016)\end{array}$ & $\begin{array}{l}-0.021 \\
(0.017)\end{array}$ & $\begin{array}{c}0.021 \\
(0.019)\end{array}$ & $\begin{array}{c}0.019 \\
(0.019)\end{array}$ \\
\hline Mother secondary education & $\begin{array}{c}0.004 \\
(0.014)\end{array}$ & $\begin{array}{l}-0.001 \\
(0.015)\end{array}$ & $\begin{array}{l}0.041^{* *} \\
(0.017)\end{array}$ & $\begin{array}{l}0.053^{* * *} \\
(0.017)\end{array}$ \\
\hline Father higher education & $\begin{array}{c}0.015 \\
(0.015)\end{array}$ & $\begin{array}{l}-0.003 \\
(0.016)\end{array}$ & $\begin{array}{l}0.083^{* * *} \\
(0.017)\end{array}$ & $\begin{array}{l}0.081^{* * *} \\
(0.018)\end{array}$ \\
\hline Mother higher education & $\begin{array}{c}0.003 \\
(0.015)\end{array}$ & $\begin{array}{l}-0.006 \\
(0.015)\end{array}$ & $\begin{array}{l}0.058^{* * *} \\
(0.018)\end{array}$ & $\begin{array}{l}0.056^{* * *} \\
(0.018)\end{array}$ \\
\hline Father's age & $\begin{array}{c}0.002 \\
(0.002)\end{array}$ & $\begin{array}{c}0.001 \\
(0.002)\end{array}$ & $\begin{array}{c}0.001 \\
(0.002)\end{array}$ & $\begin{array}{c}0.001 \\
(0.002)\end{array}$ \\
\hline age at date of interview & $\begin{array}{c}-0.005^{* * * *} \\
(0.002)\end{array}$ & $\begin{array}{l}-0.003 \\
(0.002)\end{array}$ & $\begin{array}{l}-0.004^{* *} \\
(0.002)\end{array}$ & $\begin{array}{l}-0.004^{* *} \\
(0.002)\end{array}$ \\
\hline Father working full/part-time & $\begin{array}{l}-0.014 \\
(0.047)\end{array}$ & $\begin{array}{l}0.086^{* * *} \\
(0.040)\end{array}$ & $\begin{array}{c}0.058 \\
(0.045)\end{array}$ & $\begin{array}{l}0.143^{* * * *} \\
(0.052)\end{array}$ \\
\hline Mother working full/part-time & $\begin{array}{c}0.012 \\
(0.018)\end{array}$ & $\begin{array}{l}-0.005 \\
(0.017)\end{array}$ & $\begin{array}{l}-0.016 \\
(0.017)\end{array}$ & $\begin{array}{l}-0.028 \\
(0.019)\end{array}$ \\
\hline number of people in household & $\begin{array}{l}0.029^{* * * *} \\
(0.009)\end{array}$ & $\begin{array}{l}0.024^{* * * *} \\
(0.009)\end{array}$ & $\begin{array}{l}0.025^{* * *} \\
(0.010)\end{array}$ & $\begin{array}{l}0.020^{* * *} \\
(0.010)\end{array}$ \\
\hline number of children in household & $\begin{array}{l}-0.016 \\
(0.011)\end{array}$ & $\begin{array}{c}-0.029^{* * *} \\
(0.010)\end{array}$ & $\begin{array}{l}-0.019^{*} \\
(0.010)\end{array}$ & $\begin{array}{l}-0.026^{* *} \\
(0.011)\end{array}$ \\
\hline Household owns dwelling & $\begin{array}{l}-0.011 \\
(0.018)\end{array}$ & $\begin{array}{l}-0.007 \\
(0.018)\end{array}$ & $\begin{array}{l}-0.035^{*} \\
(0.018)\end{array}$ & $\begin{array}{l}-0.035^{*} \\
(0.018)\end{array}$ \\
\hline Wave Indicator & $\begin{array}{c}0.001 \\
(0.001)\end{array}$ & $\begin{array}{c}0.001 \\
(0.001)\end{array}$ & $\begin{array}{c}-0.005^{* * *} \\
(0.002)\end{array}$ & $\begin{array}{c}-0.005^{* * *} \\
(0.002)\end{array}$ \\
\hline Constant & $\begin{array}{c}0.194 \\
(0.174)\end{array}$ & $\begin{array}{l}-0.034 \\
(0.170)\end{array}$ & $\begin{array}{c}0.157 \\
(0.136)\end{array}$ & $\begin{array}{l}-0.031 \\
(0.152)\end{array}$ \\
\hline $\begin{array}{l}\text { Hansen J statistic } \chi^{2}(1) \\
(p \text {-value })\end{array}$ & $\begin{array}{c}0.129 \\
(0.719)\end{array}$ & $\begin{array}{c}0.033 \\
(0.856)\end{array}$ & $\begin{array}{c}0.584 \\
(0.445)\end{array}$ & $\begin{array}{c}0.084 \\
(0.771)\end{array}$ \\
\hline \multicolumn{5}{|l|}{ First-stage: dep var = Log of (father's housework time +1$)$} \\
\hline Lagged egalitarian gender role attitudes & $\begin{array}{c}0.047 * * * \\
(0.017)\end{array}$ & $\begin{array}{c}0.029 * * \\
(0.016)\end{array}$ & $\begin{array}{c}0.060^{* * *} \\
(0.011)\end{array}$ & $\begin{array}{c}0.045^{* * *} \\
(0.011)\end{array}$ \\
\hline Lagged weekly working hours & $\begin{array}{l}-0.0018 * * * \\
(0.0005)\end{array}$ & $\begin{array}{c}0.0040^{* * *} \\
(0.0006)\end{array}$ & $\begin{array}{l}-0.0025 * * * \\
(0.0003)\end{array}$ & $\begin{array}{c}0.0025 * * * \\
(0.0004)\end{array}$ \\
\hline $\begin{array}{l}\text { F-test of excluded instruments } \\
\text { (p-value) }\end{array}$ & $\begin{array}{c}12.95 \\
(0.000)\end{array}$ & $\begin{array}{l}24.15 \\
(0.000)\end{array}$ & $\begin{array}{c}44.98 \\
(0.000)\end{array}$ & $\begin{array}{c}29.34 \\
(0.000)\end{array}$ \\
\hline Observations & 2,295 & 2,352 & 5,202 & 5,316 \\
\hline $\begin{array}{l}\text { Note: Robust standard errors in parentheses. }{ }^{*} p<0.1, \\
\text { living with both parents aged } 60 \text { or below, in all way } \\
\text { parents, from Waves } 12-18 \text { of the Youth Survey. Hou } \\
\text { hours do you spend on housework in an average week, } \\
\text { 1: binary indicator for disagreeing with the statement } \\
\text { and family" in wave t- } 1 \text {. }\end{array}$ & $\begin{array}{l}p<0.01 . \text { Sa } \\
\text { HPS, and in } \\
\text { e variables } c \\
\text { e spent cooki } \\
\text { s job is to ea }\end{array}$ & $\begin{array}{l}\text { consists o } \\
\text { lals aged } \\
\text { icted from } \\
\text { leaning an } \\
\text { ney; a wi }\end{array}$ & $\begin{array}{l}\text { viduals aged } 1 \\
\text { year olds liv } \\
\text { question "Abc } \\
\text { ng the laundry } \\
\text { ob is to look }\end{array}$ & $\begin{array}{l}8 \text {, who are } \\
\text { with both } \\
\text { how many } \\
\text { Instrument } \\
\text { r the home }\end{array}$ \\
\hline
\end{tabular}


Table 6: Robustness checks, the BHPS

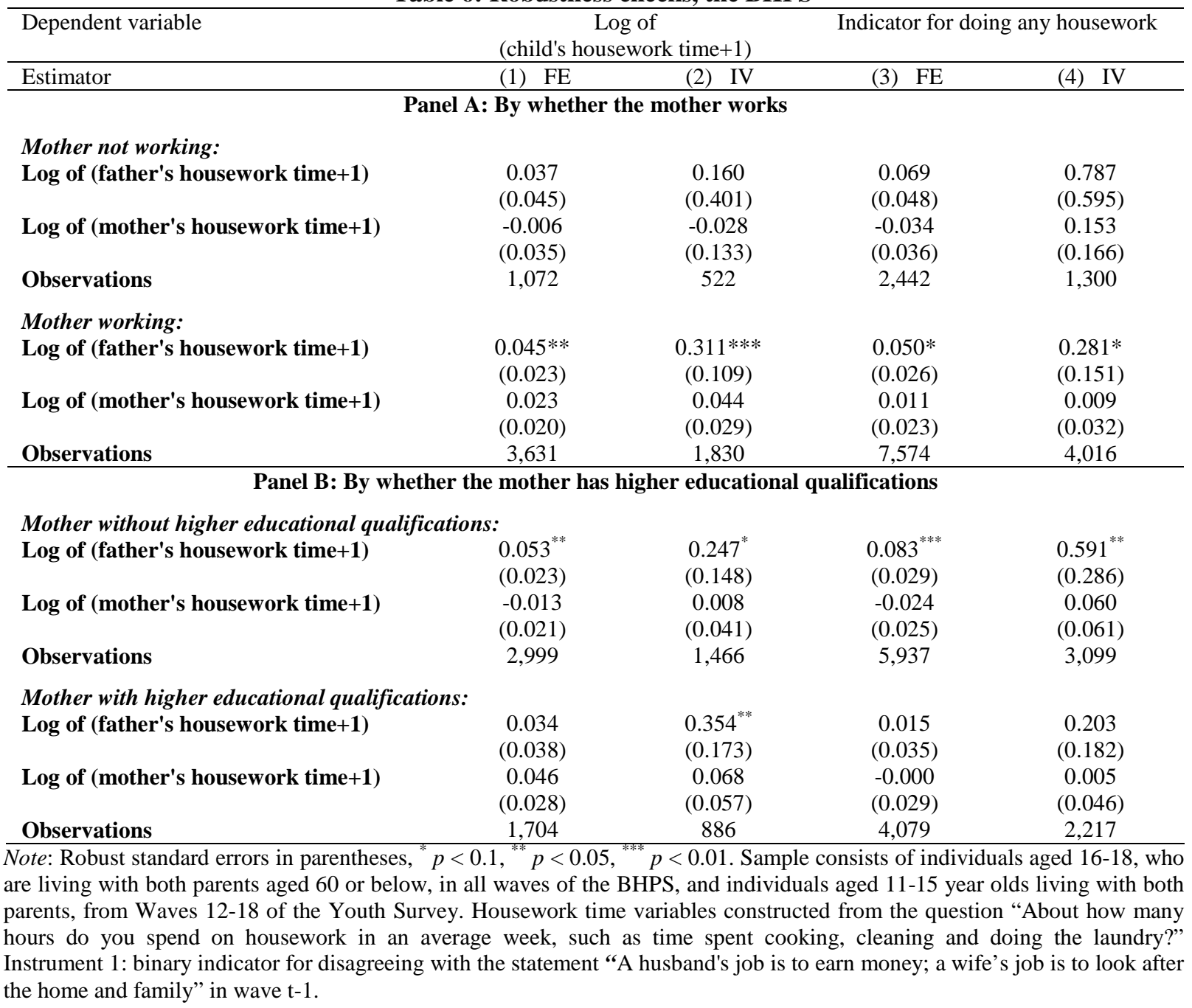




\section{APPENDIX}

Table A1. Tobit results for the United Kingdom Time Use Survey (2000)

\begin{tabular}{|c|c|c|c|c|}
\hline & \multicolumn{2}{|c|}{ Child's housework } & \multicolumn{2}{|c|}{ Child/mother housework ratio } \\
\hline & $(1)$ & $(2)$ & (3) & $(4)$ \\
\hline Father's housework & $\begin{array}{c}0.142 * * * \\
(0.03)\end{array}$ & $\begin{array}{c}0.152^{* * *} \\
(0.03)\end{array}$ & & \\
\hline Mother's housework & $\begin{array}{c}0.084^{* *} \\
(0.04)\end{array}$ & $\begin{array}{c}0.110^{* * * *} \\
(0.03)\end{array}$ & & \\
\hline Male & $\begin{array}{c}-0.280^{* * *} \\
(0.04)\end{array}$ & $\begin{array}{c}-0.298 * * * \\
-0.04\end{array}$ & $\begin{array}{c}-0.368 * * * \\
(0.08)\end{array}$ & $\begin{array}{c}-0.354^{* * *} \\
(0.06)\end{array}$ \\
\hline Age of respondent & $\begin{array}{l}0.022 * \\
(0.01)\end{array}$ & $\begin{array}{c}0.027 * * \\
-0.01\end{array}$ & $\begin{array}{l}0.038 * \\
(0.02)\end{array}$ & $\begin{array}{c}0.042^{* *} \\
(0.02)\end{array}$ \\
\hline Student & $\begin{array}{c}0.13 \\
(0.09)\end{array}$ & $\begin{array}{c}0.12 \\
-0.09\end{array}$ & $\begin{array}{l}-0.02 \\
(0.17)\end{array}$ & $\begin{array}{l}(0.00) \\
(0.14)\end{array}$ \\
\hline Unemployed & $\begin{array}{l}0.286^{*} \\
(0.16)\end{array}$ & $\begin{array}{c}0.23 \\
-0.14\end{array}$ & $\begin{array}{c}0.22 \\
(0.18)\end{array}$ & $\begin{array}{l}(0.11) \\
(0.22)\end{array}$ \\
\hline Working part-/full-time & $\begin{array}{c}-0.146^{*} \\
(0.08)\end{array}$ & $\begin{array}{c}-0.137^{*} \\
-0.08\end{array}$ & $\begin{array}{l}-0.17 \\
(0.12)\end{array}$ & $\begin{array}{l}(0.19) \\
(0.13)\end{array}$ \\
\hline Father's secondary education & $\begin{array}{c}0.04 \\
(0.05)\end{array}$ & $\begin{array}{c}0.04 \\
-0.05\end{array}$ & $\begin{array}{c}0.04 \\
(0.10)\end{array}$ & $\begin{array}{l}(0.05) \\
(0.08)\end{array}$ \\
\hline Mother's secondary education & $\begin{array}{c}0.04 \\
(0.05)\end{array}$ & $\begin{array}{c}0.04 \\
-0.05\end{array}$ & $\begin{array}{c}0.04 \\
(0.10)\end{array}$ & $\begin{array}{l}(0.05) \\
(0.07)\end{array}$ \\
\hline Father's university education & $\begin{array}{l}-0.03 \\
(0.06)\end{array}$ & $\begin{array}{l}-0.04 \\
-0.06\end{array}$ & $\begin{array}{c}0.05 \\
(0.13)\end{array}$ & $\begin{array}{l}(0.04) \\
(0.09)\end{array}$ \\
\hline Mother's university education & $\begin{array}{c}0.00 \\
(0.06)\end{array}$ & $\begin{array}{c}0.01 \\
-0.06\end{array}$ & $\begin{array}{l}-0.06 \\
(0.11)\end{array}$ & $\begin{array}{l}(0.07) \\
(0.09)\end{array}$ \\
\hline Father's age & $\begin{array}{c}0.00 \\
(0.00)\end{array}$ & $\begin{array}{l}0.00 \\
0.00\end{array}$ & $\begin{array}{c}0.00 \\
(0.01)\end{array}$ & $\begin{array}{l}(0.00) \\
(0.01)\end{array}$ \\
\hline Mother's age & $\begin{array}{c}0.00 \\
(0.01)\end{array}$ & $\begin{array}{c}0.00 \\
-0.01\end{array}$ & $\begin{array}{c}0.00 \\
(0.01)\end{array}$ & $\begin{array}{l}(0.01) \\
(0.01)\end{array}$ \\
\hline Father working part-/full-time & $\begin{array}{c}0.02 \\
(0.07)\end{array}$ & $\begin{array}{c}0.04 \\
-0.06\end{array}$ & $\begin{array}{c}0.01 \\
(0.08)\end{array}$ & $\begin{array}{l}(0.01) \\
(0.09)\end{array}$ \\
\hline Mother working part-/full-time & $\begin{array}{c}0.117^{* *} \\
(0.05)\end{array}$ & $\begin{array}{c}0.131^{* * *} \\
-0.05\end{array}$ & $\begin{array}{c}0.176^{* *} \\
(0.08)\end{array}$ & $\begin{array}{c}0.169 * * \\
(0.08)\end{array}$ \\
\hline Household size & $\begin{array}{c}0.00 \\
(0.02)\end{array}$ & $\begin{array}{l}-0.01 \\
-0.02\end{array}$ & $\begin{array}{l}-0.01 \\
(0.03)\end{array}$ & $\begin{array}{l}(0.03) \\
(0.03)\end{array}$ \\
\hline Number of children $<18$ & $\begin{array}{c}0.00 \\
(0.01)\end{array}$ & $\begin{array}{l}-0.01 \\
-0.01\end{array}$ & $\begin{array}{c}0.00 \\
(0.01)\end{array}$ & $\begin{array}{l}(0.01) \\
(0.01)\end{array}$ \\
\hline Household owns dwelling & $\begin{array}{c}0.05 \\
(0.06)\end{array}$ & $\begin{array}{c}0.06 \\
-0.05\end{array}$ & $\begin{array}{c}0.11 \\
(0.09)\end{array}$ & $\begin{array}{l}(0.10) \\
(0.08)\end{array}$ \\
\hline Father/mother housework ratio & - & $\begin{array}{l}- \\
-\end{array}$ & $\begin{array}{c}0.261 * * * \\
(0.03)\end{array}$ & $\begin{array}{c}0.255^{* * *} \\
(0.01)\end{array}$ \\
\hline Constant & $\begin{array}{l}(0.13) \\
(0.25)\end{array}$ & $\begin{array}{l}(0.15) \\
(0.25)\end{array}$ & $\begin{array}{l}(0.24) \\
(0.33)\end{array}$ & $\begin{array}{l}(0.14) \\
(0.38)\end{array}$ \\
\hline Day Fixed-Effects & Yes & Yes & Yes & Yes \\
\hline Person Random Effects & No & Yes & No & Yes \\
\hline Observations & 1,771 & 1,771 & 1,747 & 1,747 \\
\hline Pseudo R-Squared & 0.057 & - & 0.095 & - \\
\hline
\end{tabular}

Notes: Standard errors clustered at the household level in parenthesis. The sample is restricted to children who are between 11 and 18 years old, and living with two heterosexual parents from the UK. Columns (1) and (3) present results for liner Tobit, Column (2) and (4) presents results of a Random Effects Tobit model. Housework is measured in hours per day, and is defined as the sum of the time devoted to "cook, wash up", "housework", "odd jobs", "shopping” and "domestic travel." 